\title{
THE IMPACTS OF SOCIO-ECONOMIC FACTORS ON THE PERCEPTION OF RESIDENTS ABOUT URBAN VEGETATION: A COMPARATIVE STUDY OF PLANNED VERSUS SEMI-PLANNED CITIES OF ISLAMABAD AND RAWALPINDI, PAKISTAN
}

\author{
ATIF, S. B. ${ }^{1,2^{*}}-$ SAQIB, Z. $^{1}-$ ALI, A. ${ }^{3}-$ ZAMAN, M. H. ${ }^{1}$ \\ ${ }^{I}$ GIS and Eco-Informatics Laboratory, Department of Environmental Science, International \\ Islamic University, Sector H-10, 44000 Islamabad, Pakistan \\ ${ }^{2}$ Department of Geography, Government College Asghar Mall, Rawalpindi, Pakistan \\ ${ }^{3}$ Pakistan Space and Upper Atmosphere Research Commission (SUPARCO) \\ Off University Road, Karachi, Pakistan \\ *Corresponding author \\ e-mail: syedatifbokhari@gmail.com \\ (Received 22 ${ }^{\text {nd }}$ Mar 2018; accepted $20^{\text {th }}$ Jun 2018)
}

\begin{abstract}
The present study deciphers the impacts of urban planning and role of socio-economic determinants on the perception about urban vegetation. The residents inhabiting the planned (Islamabad) and the semi-planned (Rawalpindi) urban centres were the study population. Both urban areas, lying in close proximity, face rapid transformations in LULC due to urbanization. Despite their closeness, such variants as discrepancies in the standards of urban-planning and socio-economic characteristics of inhabitants make them apt study-sites. The inhabitants' perception was tapped regarding the importance of urban vegetation, temporal and spatial changes and their impacts. The majority concurred to its efficacy, a substantial proportion observed transformations in it over time while a reasonable number perceived these changes as negative and unwelcome. Such socio-economic determinants as location, education, gender, ownership status of residence and income of respondents were studied, deploying Statistical analyses (KW). Responses varied, with location and income weighing-in more heavily. Pairwise comparison (WRST) further vindicated the results. Urbanization is sure to tarnish the environmental sustainability of both cities. Synchronized efforts from all stake-holders are a must.
\end{abstract}

Keywords: urbanization, socio-economic, perception, urban ecology, urban ecosystem services, urban planning

\section{Introduction}

Life on the planet Earth is dependent on constant support and productivity of Ecosystems Services (ES) (De Groot et al., 2002). The biophysical processes and ecological systems have profound effects on the natural and social systems (Pickett et al., 2001; Alberti et al., 2003; Rockström et al., 2009; Collins et al., 2011). Since the early stages of social and societal organization, the human perception regarding the role of ecological products in their lives, witnessed many transformations in response to spatial-temporal changes.

The researchers acknowledge that human perception and interactions with the ecological resources are significantly influenced by the contextual settings (Ward Thompson et al., 2005; Nasar, 2008; Jim and Shan, 2013). The nature of these interactions significantly transform with the awareness about the benefits of these resources. In present times, these benefits are acknowledged as ES, the contributions of ecological resources towards human wellbeing (Costanza et al., 1997, 2014; De Groot et 
al., 2002). The ES are grouped into four categories i.e. provisioning, regulating, supportive and cultural (Millennium Ecosystem Assessment, 2005a; Rodríguez et al., 2006; De Groot et al., 2010).

It has been opined that the paradigm of human wellbeing is dependent upon the cumulative contribution of four types of capitals in a given geographical setting. These capitals are recognized as; the natural capital (natural resources), the human capital (human resources), the built capital (physical infrastructure) and the social capital which includes the social norms and institutions (Chiesura and De Groot, 2003; Mulder et al., 2006; Vemuri and Costanza, 2006). The human, built and social capitals have reflective effects on the contributions of natural capital towards human prosperity. The previous studies observed a symbiotic relationship between vibrant ecosystems and the quality of human life (Millennium Ecosystem Assessment, 2005b; Elmqvist et al., 2013; GómezBaggethun and Barton, 2013; Luederitz et al., 2015).

Thus, the evaluation of ES, in a given spatial setting, demands inclusion of transdisciplinary perspectives based upon contextual requirements. These assessments are also indispensable for postulating sustainable measures to enhance the performance of eco-capital i.e. ecological resources e.g. natural and manmade vegetative covers.

The previous studies have stressed on the evaluation of ecosystem services based upon holistic appraisal about the contextual demands (Millennium Ecosystem Assessment, 2003; Heal Geoffrey et al., 2005; Troy and Wilson, 2006). Thus, the identification of socio-economic factors are needed to ensure the sustainability of ecology and environment (Holling, 2001; Ostrom et al., 2001; Anton et al., 2010; Castro et al., 2011; Colding, 2013; Jim and Shan, 2013; Mcphearson et al., 2014; Kaczorowska et al., 2016; Sutton and Anderson, 2016). This realization is a precondition for sustainable development and warrants a coordinated research effort across the disciplinary divides. In response to these demands, the understanding of linkages between man and the natural environment have begun to gain momentum (Costanza and Folke, 1997; Egoh et al., 2007).

The socio-cultural transformations in a society have noteworthy impacts on the ecological resources and their performance. Agricultural activities have magnified the role of ecological resources in the wellbeing of human society (Goldblatt, 2013; Hannigan, 2014). Agricultural revolution also supported the phenomenon of permanent settlements. The urban centers are the culmination of these earlier settlements. These settlements are classified into three major types on the basis of their physical structure i.e planned, unplanned and semi planned urban settlements. Planned cities are built and progress according to a 'Master Plan', thus, displaying a perfect equilibrium of infrastructure for urban social life and ecological sustainability. While, the unplanned cities reflect no formal structure and design to achieve these goals. As compared to these types of urban settlements, the semi-planned urban settlements, grow haphazardly i.e. without any specific design or form but in the subsequent stages, its expansion and development might be regulated with planning and management instruments.

The $21^{\text {st }}$ century is being labeled as the 'urban century' due to the alarming concentration of human population in the urban areas (Benko and Strohmayer, 2014; Nersesian, 2014). The researchers supported the notions that the proportion of global population living in the urban areas is increasing (Elmqvist et al., 2013; Nations, 2014; Luederitz et al., 2015; Green et al., 2016; Larondelle and Lauf, 2016). The uncontrolled urbanization and socio-economic transformations in the urban-based activities are held responsible for unregulated land use/ land cover changes (LULC), loss of urban 
biodiversity, weather and climatic abnormalities and compromises over urban ecological managements (Grimm et al., 2008; Mcdonald et al., 2008; Seto et al., 2012; Wamsler et al., 2013; Luederitz et al., 2015; Green et al., 2016; Kaczorowska et al., 2016; Schetke et al., 2016). Veeman and Politylo (2003) and Corburn (2017) opined that the ecological degradations in the urban areas are also accountable for rising vunerabilities among the economically deprived and socially marginalized segments of society. The pressures on urban ecological resources will intensify in magnitude and complexity (Grimm et al., 2008; United-Nations, 2014; Schetke et al., 2016). Thus, the uncontrolled urbanization and ecological deteriorations in urban areas are the real challenges of the present times (Marten, 2001; Solecki et al., 2013; Sutton and Anderson, 2016) and synchronization of these two realities is incumbent for the social, economic, ecological and environmental sustainability of urban areas (Luederitz et al., 2015). The assessment of human perception about the ecological resources in a given urban milieu is, thus, a precondition for ensuring wellbeing of urban areas (Mcintyre et al., 2008; Jim and Shan, 2013; Rapoport, 2016). The developing nations are less equipped and hence less prepared to address these challenges (Schetke et al., 2016; Jim, 2013). This lack of preparedness in the developing regions is a potent threat for their urban ecological assets and social life (Morinière, 2012; Schetke et al., 2016).

The phenomena of permanent settlements in Pakistan emerged during the phase of Indus Valley Civilization (Kenoyer et al., 2013) and these settlements were urban in structure and character. The inhabitants were acquainted with the benefits of healthy environment. The subsequent socio-economic and structural transformations in this region such as canalization of the Indus Plain (Shiva, 2016) and more economic opportunities in the big cities stimulated the rural population to migrate towards these urban areas as they were already facing a paucity of basic facilities in their native rural areas. Thus, it triggered an uncontrolled urbanization of certain regions at the cost of their ecological environment. The resulting degradation in ecological resources has added stress for the urban social life in these settlements. The occurrences of erratic weather extremities such as urban heat waves and smog in winter have become a common phenomenon of big cities. These undesirable phenomena are thought to be associated with hyperactive urbanization and urban ecological degradation. Grimm et al. (2008), Wu (2008) and Qureshi et al. (2010b) anticipated that in future the process of urbanization will more accelerate in the developing countries.

The reorientation of policy to reverse the ensuing urban environmental/ecological degradation demands scientifically-based research initiatives (Kaplan and Kaplan, 1989; Jim and Shan, 2013). The inclusion of stakeholder's perception about the urban ecological resources in research and management initiatives is a prerequisite for ensuring ecological integrity and social wellbeing in the urban areas (Elkington, 1997; Sutton and Anderson, 2016).

Pakistan is among those countries where the research regarding urban environment is in its embryonic stages. Therefore, an increased focus on urban studies is required towards the assessments of urban environment and its ecological resources. In response to these demands, the research focusing on urban vegetative resources got impetus in Pakistan during the last decade. Most of the earlier research concerning urban vegetation was carried out in the contextual settings of the coastal city-Karachi. The studies such as Qureshi et al. (2010a, b, 2013) and Schetke et al. (2016) were designed to decipher the impacts and nature of relationship between urban social life and vegetative cover. However, the physical and human geography of Karachi is 
diametrically different from the urban settlements of Pothwar Plateau such as Islamabad and Rawalpindi.

In the similar time period, the researchers also tried to investigate the potentials of ecological resources and impacts of urbanization on the environmental sustainability of Islamabad and Rawalpindi. However, these studies such as Malik and Husain (2006), Jabeen et al. (2009) and Ali and Malik (2010a, b) were either inclined towards plant sciences are the studies such as Adeel (2010), Ali et al. (2011), Butt et al. (2015) and Hassan et al. (2016) were designed to decipher the impacts of urbanization on LULC changes.

Whereas, the evaluation of human perception about ecological resources is a requirement for ensuring integrated management of urban environment (Breuste, 2008; Qureshi and Breuste, 2010; Qureshi et al., 2010b). In this respect, it is apt to note that human interaction and perception about urban environment is significantly determined by societal perception about ecological resources, economic status, technological advancements, standards of urban planning, and management of existing vegetative covers in the urban regions.

The current study was designed to evaluate the impacts of socio-economic factors on the perception of urban residents about urban greenery in the planned (Islamabad) and semi-planned (Rawalpindi) urban settlements. The study hypothesizes that urban planning and socio-economic status of the inhabitants significantly influence the awareness about urban greenery.

\section{Method}

\section{Study area}

The study context is located between $72^{\circ} 55^{\prime \prime} \mathrm{E}$ to $73^{\circ} 10^{\prime \prime} \mathrm{E}$ and from $33^{\circ} 30^{\prime \prime} \mathrm{N}$ to $33^{\circ} 45^{\prime \prime} \mathrm{N}$ and comprises urban and peri-urban areas of twin cities, Islamabad and Rawalpindi. Islamabad owes its development to an administrative decision in 1959 (Maria and Imran, 2006) and was designed to serve as the capital city of Pakistan (Doxiadis, 1965). The green landscape of Islamabad was mainly inhabited by government employees besides some rural population in the vicinity. The older city of Rawalpindi, on the other hand, is a sprawling urban settlement with no formal design and infrastructure. It has less developed green areas and which are typically less taken care of.

In the recent times, the structural and social transformations in this region are responsible for the phenomena of rural to urban migration. The educated and resourceful migrants prefer to shift in Islamabad for better opportunities and peaceful urban social life. While, the economic, environmental and social migrants with less financial support find an abode in urban centers such as Rawalpindi. Resultantly, the density of human population in both urban centers is rapidly increasing (Fig. 1).

The impacts of population growth in the study area have become more visible over the period of the last ten years in the form of unregulated urban expansion. Figure 2 depicts the spatial-temporal transformations in the LULC of the study area.

The quantitative and qualitative changes in the LULC of the study area from 2005 to 2016 have been condensed in Figure 3 for comparison and brevity.

These urban centers are located in close proximity but their contrasting socioecological contextual settings and level of urban planning make it a suitable context for conducting this study of human perception. Figure 4 indicates that the respondents were 
selected from across the study area with the intent of representing the socio-economic heterogeneities of the study population.

\section{Data collection}

The data about socio-economic characteristics of respondents and their views about urban vegetation was retrieved through questionnaire method. The questionnaire was designed for deciphering the effects of socio-economic factors on the perception of respondents about urban vegetation in planned and semi planned urban areas. For this purpose, a structured questionnaire based upon literature review and feedbacks of the pilot survey was prepared.

The questionnaire is composed of two sections. The first section was designed to collect information about the economic and demographic characteristics of the respondents. The second part of the questionnaire deals with the views of the respondents about the urban vegetative cover of the study area. The respondents were required to select an option from the given format for depicting their views (Appendix 1). The questionnaire with a brief introduction about the scope and significance of the study was translated in the Urdu language for clarity and convenience of the respondents.

The residents, who were living within the metropolitan limits of Islamabad and Rawalpindi for the last ten years, were the target population. In the contextual setting of Pakistan, the head of a household significantly influences the socio-economic status and orientations of the other family members. Thus, the designated head of the family by National Database and Registration Authority (NADRA) was requested to participate in the survey as a respondent.

The sub-division of the study area into neighborhoods is a reliable sampling technique for representing social, economic and ecological heterogeneities of urban areas (Dupont, 2004). The technique was relied upon and deployed. The initial respondent from each selected locality was contacted through convenience sampling method. The rest of the respondents from the same neighborhood were approached with the help of the initial respondent on the principle of the snowballing or chain-referral sampling (Etikan et al., 2016; Marcus et al., 2017).

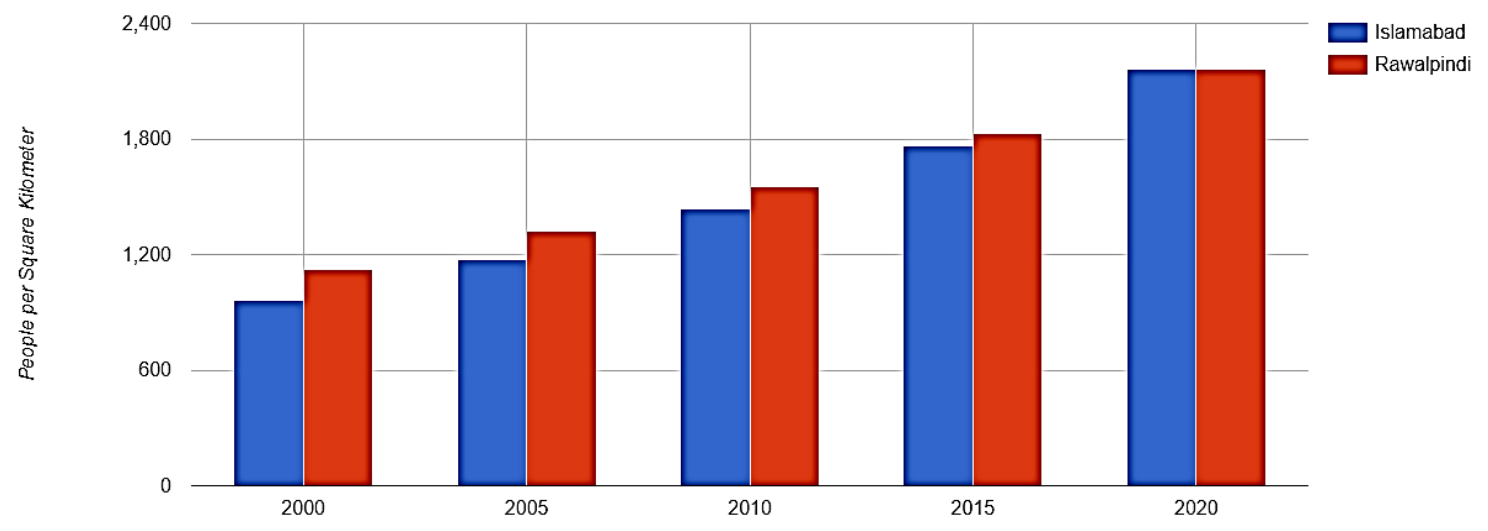

Figure 1. Estimated and Projected population density of Islamabad/ Rawalpindi. (Source:

Gridded Population of the World, Version 4. http://sedac.ciesin.columbia.edu/data/collection/gpw-v4) 

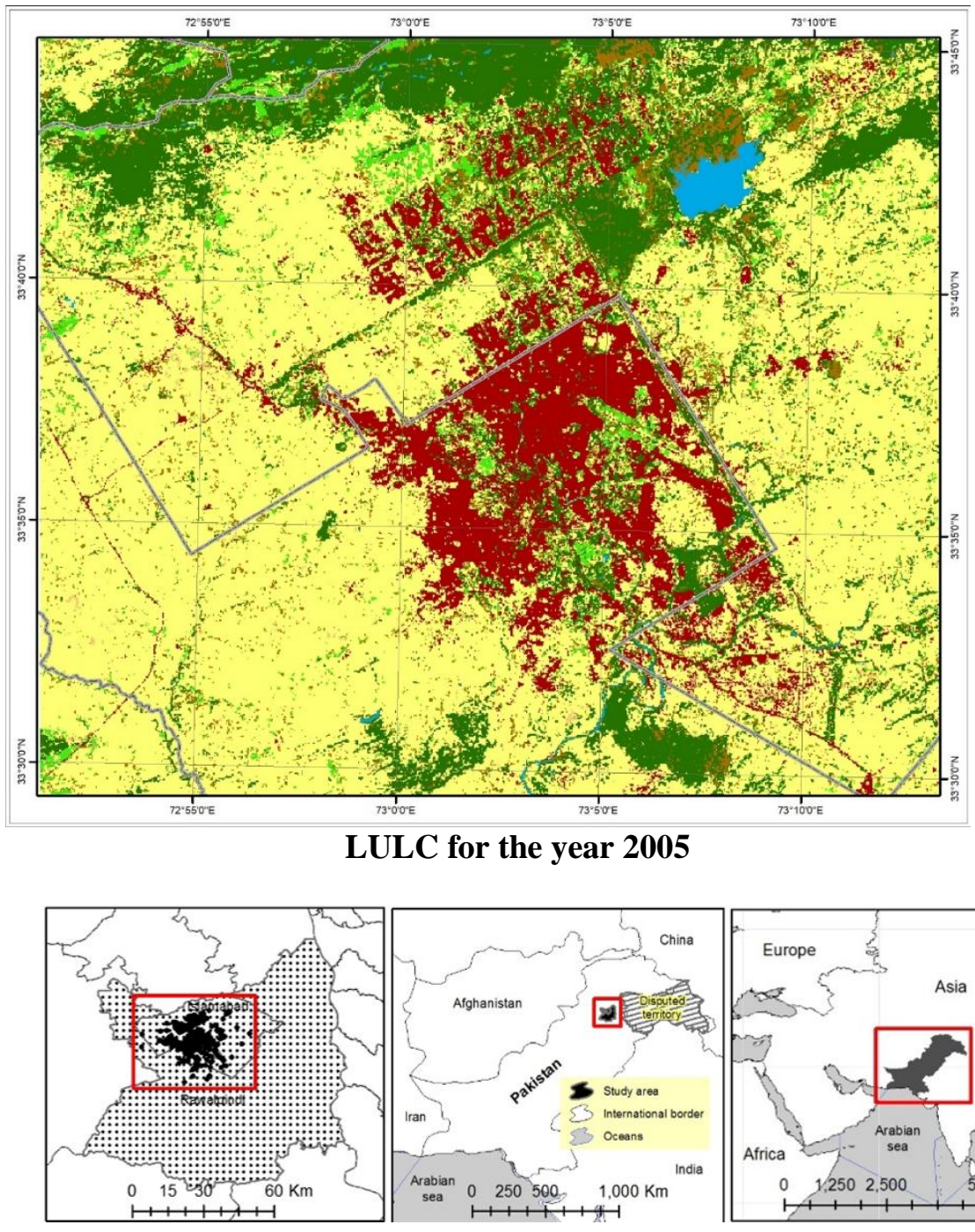
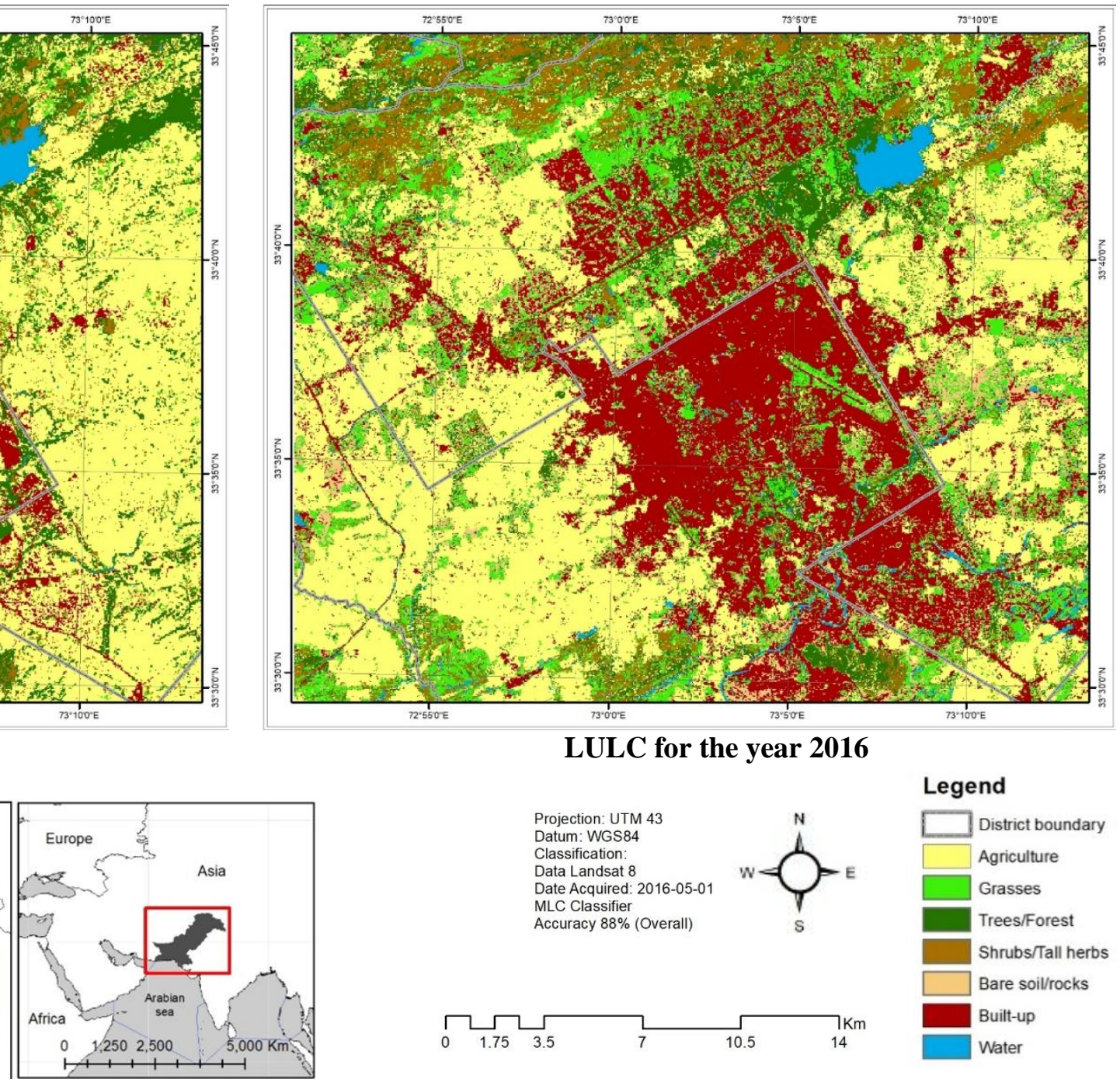

LULC for the year 2016
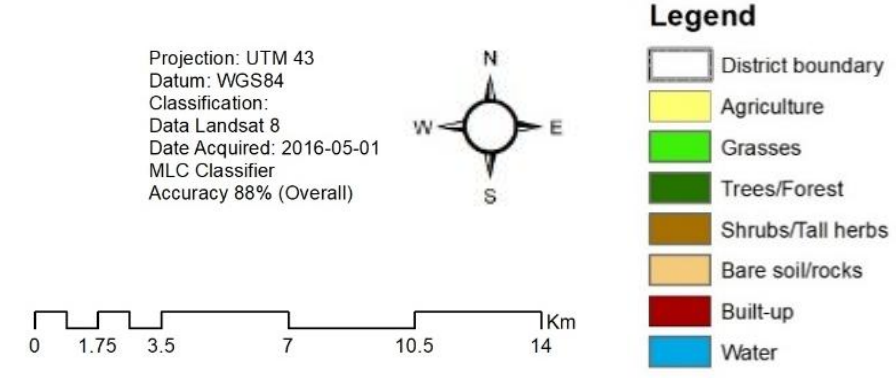

Figure 2. Portraying the LULC of the study area for the years 2005 and 2016

APPLIED ECOLOGY AND ENVIRONMENTAL RESEARCH 16(4):4265-4287.

http://www.aloki.hu • ISSN 15891623 (Print) • ISSN 17850037 (Online)

DOI: http://dx.doi.org/10.15666/aeer/1604_42654287

(c) 2018, ALÖKI Kft., Budapest, Hungary 


$$
-4271 \text { - }
$$

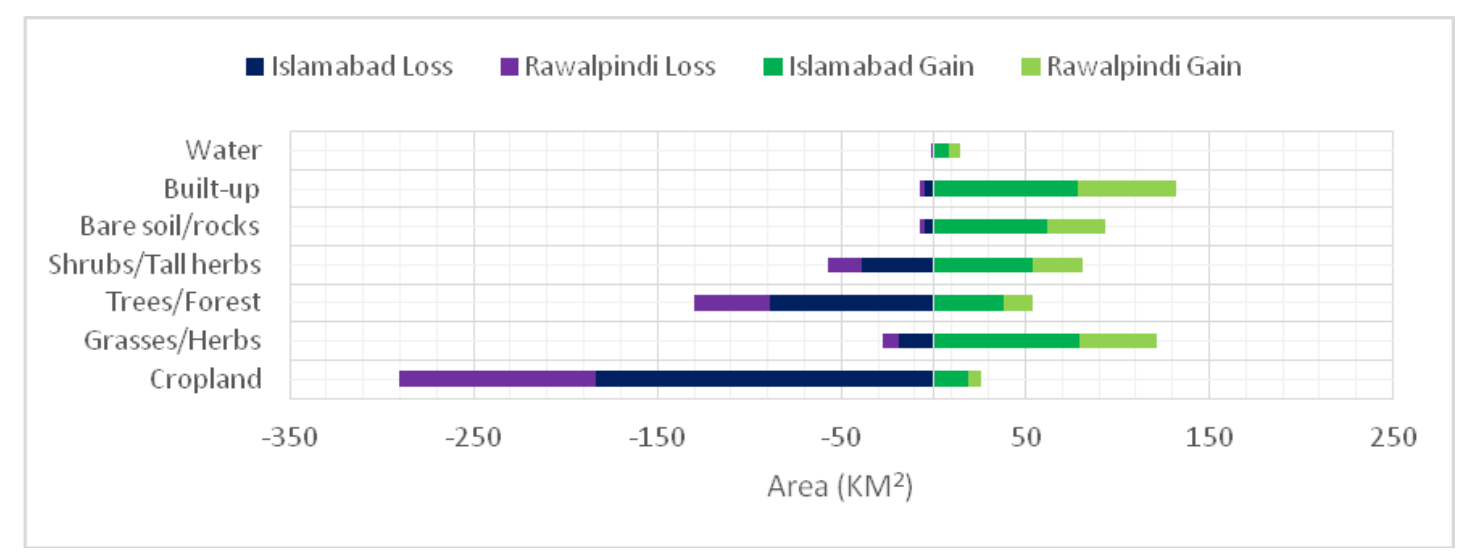

Figure 3. Comparing the changes in LULC of the study area from 2005 to 2016

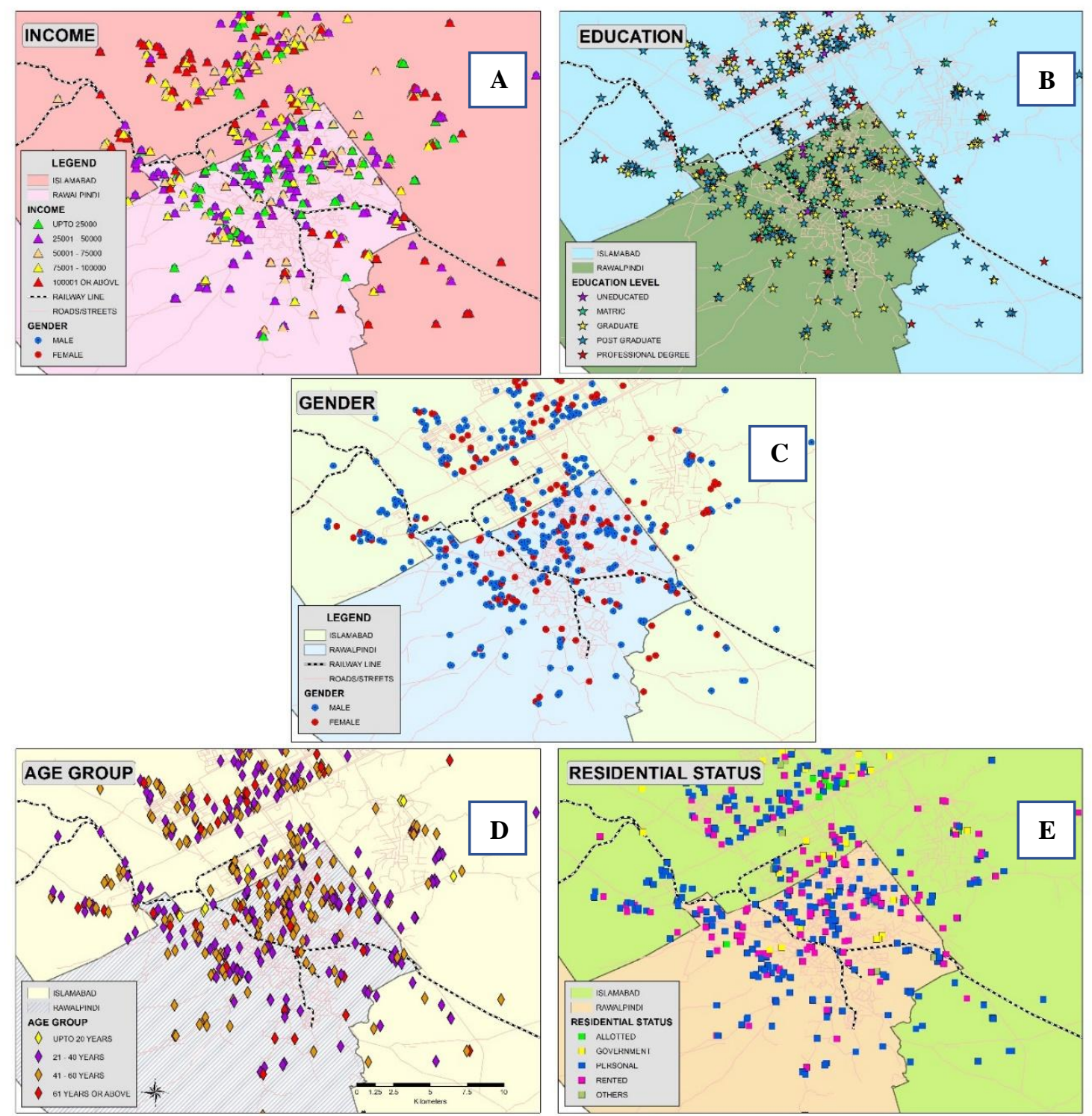

Figure 4. Maps (A-E) illustrating the spatial distribution of respondents in the study area on the basis of income, education, gender, age and residential status. 
Vollmer et al. (2015) stressed on the recording of the geo-coordinates for each data point as these information are helpful in portraying the fine scale heterogeneities of a study area. The geographic coordinates were noted down on the questionnaire at the residence of each potential respondent (Appendix 2).

The questionnaires were retrieved from the respondents after one week of delivery. On the whole, 531 questionnaires out of the distributed 800 were collected, returning an average of (66.37\%). The process was concluded during the months of July \& August 2016.

The questionnaires with incomplete records were discarded during the scrutiny. On the whole, 250 questionnaires each, from both urban centers were selected. The initial data entries were made by the researchers in Microsoft Excel (Version 2016) for subsequent processing and analysis in $\mathrm{R}$ ( $\mathrm{R}$ Version 3.4.2) program language and Geographic Information System (GIS). A portion of this data set is being used in this study.

\section{Data analysis}

Three questions about urban vegetation were asked from the respondents. The respondents were grouped on the basis of their residential location i.e. Islamabad and Rawalpindi for inter-city comparison. In the next stage, the respondents were classified and their responses were segregated on the basis of gender, education, residential status of dwellings, monthly income, and age for evaluating the role of these predictor variables in opinion building (Table 1).

Table 1. The socio-economic and demographic characteristics of respondents

\begin{tabular}{|c|c|c|}
\hline Respondents & Islamabad (\%) & Rawalpindi (\%) \\
\hline $\begin{array}{c}\text { Gender } \\
\text { Male } \\
\text { Female }\end{array}$ & $\begin{array}{c}178(71.2 \%) \\
72(28.8 \%)\end{array}$ & $\begin{array}{c}174(69.6 \%) \\
76(30.4 \%)\end{array}$ \\
\hline \multicolumn{3}{|l|}{ Education } \\
\hline $\begin{array}{l}\text { Uneducated } \\
\text { Up to matric } \\
\text { Graduate } \\
\text { Postgraduate } \\
\text { Professional }\end{array}$ & $\begin{array}{c}3(1.2 \%) \\
24(9.6 \%) \\
70(28 \%) \\
33(13.2 \%) \\
120(48 \%)\end{array}$ & $\begin{array}{c}7(2.8 \%) \\
60(24 \%) \\
89(35.6 \%) \\
9(3.6 \%) \\
85(34 \%)\end{array}$ \\
\hline \multicolumn{3}{|c|}{ Residential/ownership status of dwelling } \\
\hline $\begin{array}{c}\text { Allotted } \\
\text { Government/official } \\
\text { Personal } \\
\text { Rented } \\
\text { Others }\end{array}$ & $\begin{array}{c}9(3.6 \%) \\
27(10.8 \%) \\
137(54.8 \%) \\
73(29.2 \%) \\
4(1.6 \%)\end{array}$ & $\begin{array}{c}2(0.8 \%) \\
8(3.2 \%) \\
151(60.4 \%) \\
85(34 \%) \\
4(1.6 \%)\end{array}$ \\
\hline \multicolumn{3}{|c|}{ Monthly household income (Pak Rupees)* } \\
\hline $\begin{array}{c}\text { Up to } 25000 \\
25001 \text { to } 50000 \\
50001 \text { to } 75000 \\
75001 \text { to } 100000 \\
100001 \text { and above }\end{array}$ & $\begin{array}{l}31(12.4 \%) \\
57(22.8 \%) \\
35(14 \%) \\
53(21.2 \%) \\
74(29.6 \%)\end{array}$ & $\begin{array}{c}57(22.8 \%) \\
113(45.5 \%) \\
36(14.4 \%) \\
27(10.8 \%) \\
17(6.8 \%)\end{array}$ \\
\hline \multicolumn{3}{|l|}{ Age } \\
\hline $\begin{array}{l}\text { Up to } 20 \text { years } \\
21 \text { to } 40 \text { years } \\
41 \text { to } 60 \text { years } \\
61 \text { and above }\end{array}$ & $\begin{array}{c}31(12.4 \%) \\
103(41.2 \%) \\
110(44 \%)\end{array}$ & $\begin{array}{c}28(11.2 \%) \\
121(48.4 \%) \\
97(38.8 \%) \\
4(1.6 \%)\end{array}$ \\
\hline
\end{tabular}

*One hundred and thirty six Pak. Rupees are equal to $1 €($ EURO) on June 7, 2018 
The responses and attributes of the respondents were subsequently cross-tabulated for subsequent statistical analysis (Appendix 3).

Keeping in view the non-parametric nature of data the Kruskal-Wallis (KW) test was performed to discover the significant variations between the responses on the basis of predictor variables. In the next stage, pair -wise comparisons were carried out with the help of Wilcoxon Rank Sum Test (WRST) for those predictive variables in which the significant differences were observed in the initial KW test. The findings of WRST helped in deciphering the intra-group variations in responses. The findings were tabulated for assessments and comparisons.

\section{Results}

\section{Perception about the usefulness of urban vegetation}

The role and value of ecological contributions in a contextual setting is determined by human perception (Bixler and Floyd, 1997; Jim and Shan, 2013). The urban surroundings and socio-economic factors such as gender, education, residential status of dwellings, monthly income, and age, markedly influence the human perception about urban vegetation. The outcomes of the study (90\% respondents agreed or strongly agreed; $4.8 \%$ responded "disagree or strongly disagree" while 5.20\% stayed neutral) vindicate that the contributions of urban ecological resources stand acknowledged across the study area. However, the statistical findings ( $\left.\mathrm{KW} \chi^{2}=5.90 ; \mathrm{df}=1 ; \mathrm{p}<0.02\right)$ pointed out the significant differences between the responses of residents from both cities about the usefulness of urban vegetation.

The findings of $\mathrm{KW}$ based upon the predictor variables such as Education (KW $\chi 2$

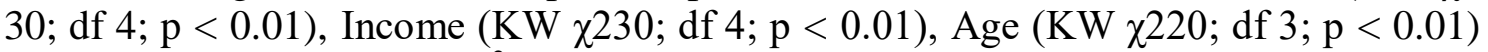
and Residential status $\left(\mathrm{KW} \chi^{2} 10 ; \mathrm{df} 4 ; \mathrm{p}<0.02\right)$ indicated that these predictor variables also have a significant influence on the perception of respondents regarding the usefulness of urban vegetation (Table 2). However, the test statistics (KW $\chi^{2} 0.3$; df 1 ; $\mathrm{p}>0.05$ ) indicate that the Gender of respondent has a less significant role in this connection.

Table 2. The findings of Kruskal-Wallis $(K W)$ test based upon of socio-economic variables

\begin{tabular}{c|c|c|c|c|c|c|c|c|c|c}
\hline \multicolumn{8}{c}{ Kruskal-Wallis (KW) test and views of respondents } \\
\hline & \multicolumn{2}{|c|}{ Chi square value } & \multicolumn{2}{|c}{$\begin{array}{c}\text { Degree of freedom } \\
\text { (df) }\end{array}$} & \multicolumn{4}{c}{ P value } \\
\hline Predictor variables & UVBR & VCC & ICUV & UVBR & VCC & ICUV & UVBR & VCC & ICUV \\
\hline Gender & 0.3 & 0.5 & 4 & 1 & 1 & 1 & 0.6 & 0.5 & 0.05 \\
Education & 30 & 10 & 4 & 4 & 4 & 4 & 0.0000006 & 0.05 & 0.4 \\
Residential status & 10 & 10 & 7 & 4 & 4 & 4 & 0.02 & 0.03 & 0.2 \\
Income & 30 & 20 & 20 & 4 & 4 & 4 & 0.000002 & 0.001 & 0.0001 \\
Age & 20 & 20 & 1 & 3 & 3 & 3 & 0.0007 & 0.001 & 0.8 \\
\hline
\end{tabular}

Urban Vegetation is Beneficial for Residents (UVBR); Vegetation Cover Changes (VCC); Impacts of Changes in Urban Vegetation (ICUV)

The predictor variables identified in $\mathrm{KW}$ as responsible for significant differences were further tested for pair-wise comparison by WRST. The findings $(p<0.05)$ of 
WRST based upon educational background revealed significant differences in the responses between the lesser or uneducated and educated respondents (Appendix 4a). This clearly implies that the level of education has significant bearings on the human perception about the benefits of natural capital. The ownership status of the dwelling is another important socio-economic indicator and meaningfully influences the opinions of people about the benefits of urban ecology. The marked variations $(p<0.05)$ among the views of respondents residing in different categories of accommodations were also observed in the findings of WRST (Appendix 4b).

The age-based comparison of WRST among different age groups (Appendix 4c) revealed significant differences $(\mathrm{p}<01)$ between the responses of the most senior age group (61 years and above) with all other age groups (up to 20 years; $21-40$ years; 4160 years). The significant variations in views were not found between all the other categories of age groups. The income of respondents was also observed to be an influential factor in shaping the perception of respondents about the usefulness of urban vegetation. The pair wise comparison of income based categories in (Appendix 4d) indicated that the two lowest income groups (Up to Rs. 25000, Rs. 25001 to 50000) have a significantly different perception about the importance of urban greenery $(\mathrm{p}<$ 01) than the respondents from three higher income categories (Rs. 50001 to 75000, Rs. 75001 to 100000 , and Rs. 100001 and above).

\section{Perception of respondents about change in urban vegetation}

The respondents were enquired about the vegetation cover changes in the study area. The majority of the respondents $(69.20 \%)$ observed that the vegetative cover of Islamabad and Rawalpindi is changing and $12.80 \%$ reported that they do not perceive any visible change in it. Whereas, the remaining $18 \%$ of respondents have no considered opinion about the phenomenon.

However, the test statistics $\left(\mathrm{KW} \chi^{2} 5.26\right.$; df $\left.1 ; \mathrm{p}<0.02\right)$ identified the significant variations in the responses of inhabitants from both urban centers regarding the changes in vegetation cover. The significant variations in the responses were also found on the basis of socio-economic factors such as Education (KW $\left.\chi^{2} 10 ; \mathrm{df} 4 ; \mathrm{p}<0.05\right)$, Residential status (KW $\left.\chi^{2} 10 ; \mathrm{df} 4 ; \mathrm{p}<0.03\right)$, Income (KW $\left.\chi^{2} 20 ; \mathrm{df} 4 ; \mathrm{p}<0.001\right)$ and Age $\left(\mathrm{KW} \chi^{2} 20\right.$; df $\left.3 ; \mathrm{p}<0.001\right)$. However, the role of Gender was found negligible in this regard $\left(\mathrm{KW} \chi^{2} 0.5 ; \mathrm{df} 1 ; \mathrm{p}>0.5\right)$ (Table 2).

The subsequent findings of WRST $(\mathrm{p}<0.05)$ revealed meaningful variations among the different categories of respondents on the basis of education (Appendix 5a). In this connection, significant differences $(p<0.05)$ were also observed in the opinions of respondents living in the rented dwellings with those who are living in government residences or in their personal abodes (Appendix 5b). These statistical findings infer that the ownership status of dwelling influences the opinions of people about changes in urban vegetation.

The significant differences in the opinions $(\mathrm{p}<0.01)$ about the phenomenon were also observed in the findings of WRST between the responses of age group (61years and above) with all other ages based categories (Appendix 5c). While, the Income based pair wise comparison based upon WRST indicated that the lowest income group (up to Rs. 25000) had a significantly different perception $(\mathrm{p}<0.01)$ about the changes in vegetation cover of the study area than all the other income based categories of respondents (Appendix 5d). 


\section{Impacts of vegetative cover changes and respondents}

The changes in the vegetative cover of the study area were negatively perceived by the majority $(55.80 \%)$ of respondents. The significant differences in views regarding the impacts of these changes were also observed on the basis of residential location i.e. Islamabad or Rawalpindi (KW $\chi^{2} 7.37$;f $\left.1 ; \mathrm{p}<0.01\right)$ and socio-economic factors such as Gender $\left(\mathrm{KW} \chi^{2} 4\right.$; df $\left.1 ; \mathrm{p}<0.05\right)$ and Income $\left(\mathrm{KW} \chi^{2} 20 ; \mathrm{df} 4 ; \mathrm{p}<0.01\right)$. However, the test statistics based upon KW in (Table 2) depicted that the predictor variables such as Education, Residential status and Age of respondents have an ineffective influence on the views of residents in the study context.

The (KW) findings revealed that the gender of respondents had, yet, a different type of influence on perceptions regarding outcomes of change in the urban vegetative cover of the study area (Table 2).

The succeeding findings based upon WRST suggested that the economic status of urban residents has significant bearings on their views about the consequences of changes in vegetation cover (Appendix 6e). The pair wise findings of WRST based upon categories of education (Appendix 6b) pointed towards significant variations in perception about the impacts of changes $(\mathrm{p}<0.05)$ between uneducated and higher educated respondents. However, such differences were found to be insignificant between uneducated and moderately educated respondents.

\section{Discussion}

The study evaluated socio-economic impacts and role of urban planning in shaping the perceptions of urban residents about ecological resources. The study was carried out in the contextual setting of Islamabad and Rawalpindi in Pakistan. The findings of the study establish that the process of urbanization is gaining momentum. The previous studies (Ali and Malik, 2010b; Ali et al., 2011; Ghafoor Chaudhry et al., 2014) returned similar conclusions. The critical findings of the study also formulate that urbanization through LULC changes is responsible for transformations in the ecology of the study area. These findings give credibility to the assertions of Ali and Malik (2010b) and Faeth et al. (2011) that urbanization causes and stimulates changes in the urban vegetation.

The majority (90\%) of the respondents affirmed the positive contributions of urban ecological resources. The finding is in line with the opinions of Kaplan and Kaplan (1989) and Qureshi et al. (2010b) that urban residents acknowledge the importance of ecological contributions.

However, the findings divulge that the residential location and socio-economic characteristics of the study population are accountable for significant variations in views about the various aspects of urban vegetation. The outcomes of subsequent analysis vindicate the assertions that human perspectives about vegetative cover are significantly influenced by the level of education (Tidball and Krasny, 2011; Rupprecht and Byrne, 2014), ownership status of the inhabitant (Van Heezik et al., 2013; Shakeel and Conway, 2014), age (Lee and Maheswaran, 2011), income (Lee and Maheswaran, 2011; Majumdar et al., 2011) and gender (Gidlöf-Gunnarsson and Öhrström, 2010; Lee and Maheswaran, 2011).

The statistical findings based on empirical data validate the differences in the views of respondents from both urban centers about the transformation in vegetative cover. These variations in opinions are attributable to quantitative and qualitative differences 
in socio-ecological settings of both cities. The urban vegetative cover, city structure, level of urban planning and management of urban ecological resources in Islamabad and Rawalpindi are inherently different. The former urban settlement is comparatively greener, broader in structure, more planned and administered by a well-structured and resourceful organization. As compared to it, Rawalpindi is a semi planned city, a victim of compromised environmental governance and unregulated and disorderly urban expansion.

However, this acknowledgement of change in urban vegetation is not homogenous among the different socio-economic segments of the study population. The summary statistics of data illustrate significant heterogeneities among the opinions of respondents on the basis of their awareness and sensitivity. The socio-economic trajectories of respondents were found influential in shaping their perception regarding changes in urban vegetation. These observations are in line with the previous assertions (Faeth et al., 2011; Kowarik, 2011) that socio-economic factors suggestively influence the human perception about changes in urban vegetative cover.

The variations in views about the impacts of changes on the basis of gender, support the previous findings (Gidlöf-Gunnarsson and Öhrström, 2010; Lee and Maheswaran, 2011) that the gender of respondents influences the human perception about humanenvironment relationships. In conservative social settings of the developing world, unequal exposures between male and female, is responsible for differences in normative knowledge about urban vegetation. Thus, it offers a plausible explanation for reported dissimilarities in views.

The study also substantiates the notions of reported findings (Jim and Shan, 2013; Mcguirk, 2013) that income, a proxy variable for economic status of individuals, not only determines socio-economic standings of the individuals but also significantly influences their propensities towards ecological resources. It is the considered opinion of the authors of this study that in the present age of consumerism and knowledge based economy the role of income and education is becoming more influential in shaping the perception of respondents regarding urban ecological resources.

\section{Conclusions}

The present study evaluated the role of urban planning and socio-economic factors i.e. gender, education, residential status of dwellings, monthly income, and age, in shaping the perception of respondents about ecological resources in the study area. The findings of the study indicate that the level of urban planning, exposure to ecological resources, socio-economic and demographic characteristics of the urban population have significant bearings on their orientations towards green infrastructure of urban areas. The study also points towards the growing urbanization and rapid transformations in LULC of the study area. The resultant impacts of these intrusions may adversely impact the performance and sustainability of the urban environment in both cities. The synchronized efforts of researchers, opinion builders, policy makers, concerned institutions and proactive participation of urban residents are required for integrated management and sustainability of the urban environment. In this connection further research is needed for evaluating the orientation of spatial and temporal changes in the LULC of the study area. The use of Remote Sensing (RS) data with the help of Geographic Information System (GIS) techniques seems to be a pragmatic option for measuring these trends. The findings of this study also signify the role and importance 
of environmental management for the sustainability of urban green resources. Therefore, further investigations are also required for assessing the role and performance of institutions responsible for the environmental management of the study area. The holistic appraisal about such dimensions of environmental management are imperative for a healthy, green urban infrastructure.

Acknowledgements. The authors of this manuscript are highly indebted to anonymous reviewers for their invaluable suggestions and comments for improving the orientation and quality of the manuscript.

\section{REFERENCES}

[1] Adeel, M. (2010): Methodology for identifying urban growth potential using land use and population data: A case study of Islamabad Zone IV. - Procedia Environmental Sciences 2: $32-41$.

[2] Alberti, M., Marzluff, J. M., Shulenberger, E., Bradley, G., Ryan, C., Zumbrunnen, C. (2003): Integrating humans into ecology: opportunities and challenges for studying urban ecosystems. - BioScience 53: 1169-1179.

[3] Ali, M., Khan, S. J., Aslam, I., Khan, Z. (2011): Simulation of the impacts of land-use change on surface runoff of Lai Nullah Basin in Islamabad, Pakistan. - Landscape and Urban Planning 102: 271-279.

[4] Ali, S. M., Malik, R. N. (2010a): Spatial patterns of vegetation with underlying soil properties prevailing along drain side areas in Islamabad city. - Pak. J. Bot. 42: 23972410.

[5] Ali, S. M., Malik, R. N. (2010b): Vegetation communities of urban open spaces: Green belts and parks in Islamabad city. - Pak. J. Bot. 42: 1031-1039.

[6] Anton, C., Young, J., Harrison, P. A., Musche, M., Bela, G., Feld, C. K., Harrington, R., Haslett, J. R., Pataki, G., Rounsevell, M. D. (2010): Research needs for incorporating the ecosystem service approach into EU biodiversity conservation policy. - Biodiversity and Conservation 19: 2979-2994.

[7] Baklanov, A., Molina, L. T., Gauss, M. (2016): Megacities, air quality and climate. Atmospheric Environment 126: 235-249.

[8] Benko, G., Strohmayer, U. (2014): Human Geography: A History for the Twenty-First Century. - Routledge, London.

[9] Bixler, R. D., Floyd, M. F. (1997): Nature is scary, disgusting, and uncomfortable. Environment and Behavior 29: 443-467.

[10] Breuste, J. (2008): Ecological Perspectives of Urban Green and Open Spaces. Selbstverl. des Fachbereiches Geographie und Geologie der Univ. Salzburg.

[11] Butt, A., Shabbir, R., Ahmad, S. S., Aziz, N. (2015): Land use change mapping and analysis using Remote Sensing and GIS: A case study of Simly watershed, Islamabad, Pakistan. - The Egyptian Journal of Remote Sensing and Space Science 18: 251-259.

[12] Castro, A. J., Martín-López, B., García-Llorente, M., Aguilera, P. A., López, E., Cabello, J. (2011): Social preferences regarding the delivery of ecosystem services in a semiarid Mediterranean region. - Journal of Arid Environments 75: 1201-1208.

[13] Chiesura, A., De Groot, R. (2003): Critical natural capital: a socio-cultural perspective. Ecological Economics 44: 219-231.

[14] Colding, J. (2013): Local Assessment of Stockholm: Revisiting the Stockholm Urban Assessment. Urbanization, Biodiversity and Ecosystem Services: Challenges and Opportunities. - Springer, London.

[15] Collins, S. L., Carpenter, S. R., Swinton, S. M., Orenstein, D. E., Childers, D. L., Gragson, T. L., Grimm, N. B., Grove, J. M., Harlan, S. L., Kaye, J. P. (2011): An 
integrated conceptual framework for long-term social-ecological research. - Frontiers in Ecology and the Environment 9: 351-357.

[16] Costanza, R., Folke, C. (1997): Valuing Ecosystem Services with Efficiency, Fairness and Sustainability as Goals. - In: Daily, G. (ed.) Nature's Services: Societal Dependence on Natural Ecosystems, pp. 49-70. Island Press, Washington DC.

[17] Costanza, R., D’arge, R., De Groot, R., Farber, S., Grasso, M., Hannon, B., Limburg, K., Naeem, S., O'neill, R. V., Paruelo, J. (1997): The value of the world's ecosystem services and natural capital. - Nature 387: 253-260.

[18] Costanza, R., De Groot, R., Sutton, P., Van Der Ploeg, S., Anderson, S. J., Kubiszewski, I., Farber, S., Turner, R. K. (2014): Changes in the global value of ecosystem services. Global Environmental Change 26: 152-158.

[19] De Groot, R. S., Alkemade, R., Braat, L., Hein, L., Willemen, L. (2010): Challenges in integrating the concept of ecosystem services and values in landscape planning, management and decision making. - Ecological Complexity 7: 260-272.

[20] De Groot, R. S., Wilson, M. A., Boumans, R. M. (2002): A typology for the classification, description and valuation of ecosystem functions, goods and services. Ecological Economics 41: 393-408.

[21] Doxiadis, C. A. (1965): Islamabad, the creation of a new capital. - Town Planning Review 36: 1.

[22] Dupont, V. (2004): Socio-spatial differentiation and residential segregation in Delhi: a question of scale? - Geoforum 35: 157-175.

[23] Egoh, B., Rouget, M., Reyers, B., Knight, A. T., Cowling, R. M., Van Jaarsveld, A. S., Welz, A. (2007): Integrating ecosystem services into conservation assessments: a review. - Ecological Economics 63: 714-721.

[24] Elkington, J. (1997): Cannibals with Forks. The Triple Bottom Line of 21st Century. Capstone, Oxford.

[25] Elmqvist, T., Fragkias, M., Goodness, J., Güneralp, B, Marcotullio, P. J., McDonald. R. I., Parnell, S., Schewenius, M., Sendstad, M., Seto, K. C., Wilkinson, C. (eds.) (2013): Urbanization, Biodiversity and Ecosystem Services: Challenges and Opportunities. Springer, Netherlands.

[26] Etikan, I., Alkassim, R., Abubakar, S. (2016): Comparision of Snowball Sampling and Sequential Sampling Technique. - Biometrics and Biostatistics International Journal. 3: 00055 .

[27] Faeth, S. H., Bang, C., Saari, S. (2011): Urban biodiversity: patterns and mechanisms. Annals of the New York Academy of Sciences 1223: 69-81.

[28] Ghafoor Chaudhry, A., Ellahi Khan, S., Ahmed, A., Khan, N. (2014): The begging Hijras of Islamabad in the age of urbanization: an anthropological perspective. - Science International 26(5): 2553-2555.

[29] Gidlöf-Gunnarsson, A., Öhrström, E. (2010): Attractive "quiet" courtyards: a potential modifier of urban residents' responses to road traffic noise? - International Journal of Environmental Research and Public Health 7: 3359-3375.

[30] Goldblatt, D. (2013): Social Theory and the Environment. - John Wiley \& Sons, Chichester.

[31] Gómez-Baggethun, E., Barton, D. N. (2013): Classifying and valuing ecosystem services for urban planning. - Ecological Economics 86: 235-245.

[32] Green, T. L., Kronenberg, J., Andersson, E., Elmqvist, T., Gómez-Baggethun, E. (2016): Insurance value of green infrastructure in and around cities. - Ecosystems 19: 1051-1063.

[33] Grimm, N. B., Faeth, S. H., Golubiewski, N. E., Redman, C. L., Wu, J., Bai, X., Briggs, J. M. (2008): Global change and the ecology of cities. - Science 319: 756-760.

[34] Hannigan, J. (2014): Environmental Sociology Third Edition. - Routledge, London.

[35] Hassan, Z., Shabbir, R., Ahmad, S. S., Malik, A. H., Aziz, N., Butt, A., Erum, S. (2016): Dynamics of land use and land cover change (LULCC) using geospatial techniques: a case study of Islamabad Pakistan. - SpringerPlus 5: 1-11. 
[36] Heal Geoffrey, M., Barbier Edward, B., Boyle Kevin, J., Covich Alan, P., Gloss Stephen, P., Hershner Carl, H., Hoehn John, P., Pringle Catherine, M., Polasky Stephen, S. K. (2005): Shrader-Frechette Kirstin. Valuing Ecosystem Services: Toward Better Environmental Decision Making. - National Academies Press, Washington, DC.

[37] Holling, C. (2001): Understanding the complexity of economic, ecological and social systems. - Ecosystems 4(5): 390-405.

[38] Jabeen, A., Khan, M. A., Ahmad, M., Zafar, M., Ahmad, F. (2009): Indigenous uses of economically important flora of Margallah hills national park, Islamabad, Pakistan. African Journal of Biotechnology 8(5): 763-784.

[39] Jim, C., Shan, X. (2013): Socioeconomic effect on perception of urban green spaces in Guangzhou, China. - Cities 31: 123-131.

[40] Kaczorowska, A., Kain, J.-H., Kronenberg, J., Haase, D. (2016): Ecosystem services in urban land use planning: integration challenges in complex urban settings - case of Stockholm. - Ecosystem Services 22: 204-212.

[41] Kaplan, R., Kaplan, S. (1989): The Experience of Nature: A Psychological Perspective. CUP Archive, Cambridge.

[42] Kenoyer, J. M., Price, T. D., Burton, J. H. (2013): A new approach to tracking connections between the Indus Valley and Mesopotamia: initial results of strontium isotope analyses from Harappa and Ur. - Journal of Archaeological Science 40: 22862297.

[43] Kowarik, I. (2011): Novel urban ecosystems, biodiversity, and conservation. Environmental Pollution 159: 1974-1983.

[44] Larondelle, N., Lauf, S. (2016): Balancing demand and supply of multiple urban ecosystem services on different spatial scales. - Ecosystem Services 22: 18-31.

[45] Lee, A. C., Maheswaran, R. (2011): The health benefits of urban green spaces: a review of the evidence. - Journal of Public Health 33: 212-222.

[46] Luederitz, C., Brink, E., Gralla, F., Hermelingmeier, V., Meyer, M., Niven, L., Panzer, L., Partelow, S., Rau, A.-L., Sasaki, R. (2015): A review of urban ecosystem services: six key challenges for future research. - Ecosystem Services 14: 98-112.

[47] Majumdar, S., Deng, J., Zhang, Y., Pierskalla, C. (2011): Using contingent valuation to estimate the willingness of tourists to pay for urban forests: A study in Savannah, Georgia. - Urban Forestry \& Urban Greening 10: 275-280.

[48] Malik, R. N., Husain, S. Z. (2006): Classification and ordination of vegetation communities of the Lohibehr reserve forest and its surrounding areas, Rawalpindi, Pakistan. - Pakistan Journal of Botany 38: 543.

[49] Marcus, B., Weigelt, O., Hergert, J., Gurt, J., Gelléri, P. (2017): The use of snowball sampling for multi source organizational research: Some cause for concern. - Personnel Psychology 70: 635-673.

[50] Maria, S. I., Imran, M. (2006): Planning of Islamabad and Rawalpindi: What went wrong. - Paper presented at the $42^{\text {nd }}$ ISoCaRP Congresss, Istanbul, Turkey, 14-18 September 2006.

[51] Marten, G. G. (2001): Human Ecology: Basic Concepts for Sustainable Development. Earthscan, London.

[52] Mcdonald, R. I., Kareiva, P., Forman, R. T. (2008): The implications of current and future urbanization for global protected areas and biodiversity conservation. - Biological Conservation 141: 1695-1703.

[53] Mcguirk, E. F. (2013): The illusory leader: natural resources, taxation and accountability. - Public Choice 154(3-4): 285-313.

[54] Mcintyre, N. E., Knowles-Yánez, K., Hope, D. (2008): Urban Ecology as an Interdisciplinary Field: Differences in the Use of "Urban" between the Social and Natural Sciences. - In: Marzluff, J. M. et al. (eds): Urban Ecology. Springer, Boston MA.

[55] Mcphearson, T., Hamstead, Z. A., Kremer, P. (2014): Urban ecosystem services for resilience planning and management in New York City. - Ambio 43: 502-515. 
[56] Millennium Ecosystem Assessment (2003): Millennium Ecosystem Assessment. - Island, Washington.

[57] Millennium Ecosystem Assessment (2005a): Ecosystems and Human Well-Being: Synthesis. - Island, Washington, DC.

[58] Millennium Ecosystem Assessment (2005b): Millennium Ecosystem Assessment. Ecosystems and Human Well-Being: Biodiversity Synthesis. - Island, Washington, DC.

[59] Morinière, L. (2012): Environmentally influenced urbanisation: Footprints bound for town? - Urban Studies 49: 435-450.

[60] Mulder, K., Costanza, R., Erickson, J. (2006): The contribution of built, human, social and natural capital to quality of life in intentional and unintentional communities. Ecological Economics 59: 13-23.

[61] Nasar, J. L. (2008): Assessing perceptions of environments for active living. - American Journal of Preventive Medicine 34: 357-363.

[62] Nations, U. (2014): World Urbanization Prospects: The 2014 Revision, Highlights. Department of Economic and Social Affairs. - Population Division, United Nations.

[63] Nersesian, R. (2014): Energy for the 21st Century: a Comprehensive Guide to Conventional and Alternative Sources. - Routledge, London.

[64] Ostrom, E., Costanza, R., Low, B., Wilson, J. (2001): Institutions, Ecosystems and Sustainability. - Lewis Publishers, New York.

[65] Pickett, S. T., Cadenasso, M. L., Grove, J. M., Nilon, C. H., Pouyat, R. V., Zipperer, W. C., Costanza, R. (2001): Urban ecological systems: Linking terrestrial ecological, physical, and socioeconomic components of metropolitan areas 1. - Annual Review of Ecology and Systematics 32: 127-157.

[66] Qureshi, S., Breuste, J. H. (2010): Prospects of Biodiversity in the Mega City Karachi, Pakistan: Potentials, Constraints and Implications. Urban Biodiversity and Design: Implementing the Convention on Biological Diversity in Towns and Cities. - WileyBlackwell, Oxford, pp. 497-517.

[67] Qureshi, S., Breuste, J. H., Jim, C. (2013): Differential community and the perception of urban green spaces and their contents in the megacity of Karachi, Pakistan. - Urban Ecosystems 16: 853-870.

[68] Qureshi, S., Breuste, J. H., Lindley, S. J. (2010a): Green space functionality along an urban gradient in Karachi, Pakistan: a socio-ecological study. - Human Ecology 38: 283294.

[69] Qureshi, S., Kazmi, S. J. H., Breuste, J. H. (2010b): Ecological disturbances due to high cutback in the green infrastructure of Karachi: Analyses of public perception about associated health problems. - Urban Forestry \& Urban Greening 9: 187-198.

[70] Rapoport, A. (2016): Human Aspects of Urban Form: Towards a Man-Environment Approach to Urban Form and Design. - Elsevier, New York.

[71] Rockström, J., Steffen, W., Noone, K., Persson, Ö., Chapin Iii, F. S., Lambin, E., Lenton, T., Scheffer, M., Folke, C., Schellnhuber, H. J. (2009): Planetary boundaries: exploring the safe operating space for humanity. - Ecology and Society 14(2): 32.

[72] Rodríguez, J. P., Beard Jr, T. D., Bennett, E. M., Cumming, G. S., Cork, S. J., Agard, J., Dobson, A. P., Peterson, G. D. (2006): Trade-offs across space, time, and ecosystem services. - Ecology and Society 11(1): 28.

[73] Rupprecht, C. D., Byrne, J. A. (2014): Informal urban greenspace: A typology and trilingual systematic review of its role for urban residents and trends in the literature. Urban Forestry \& Urban Greening 13: 597-611.

[74] Schetke, S., Qureshi, S., Lautenbach, S., Kabisch, N. (2016): What determines the use of urban green spaces in highly urbanized areas? - Examples from two fast growing Asian cities. - Urban Forestry \& Urban Greening 16: 150-159.

[75] Seto, K. C., Güneralp, B., Hutyra, L. R. (2012): Global forecasts of urban expansion to 2030 and direct impacts on biodiversity and carbon pools. - Proceedings of the National Academy of Sciences 109: 16083-16088. 
[76] Shakeel, T., Conway, T. M. (2014): Individual households and their trees: Fine-scale characteristics shaping urban forests. - Urban Forestry \& Urban Greening. 13: 136-144.

[77] Shiva, V. (2016): The Violence of the Green Revolution: Third World Agriculture, Ecology, and Politics. - University Press of Kentucky, Lexington.

[78] Solecki, W., Seto, K. C., Marcotullio, P. J. (2013): It's time for an urbanization science. Environment: Science and Policy for Sustainable Development 55: 12-17.

[79] Sutton, P. C., Anderson, S. J. (2016): Holistic valuation of urban ecosystem services in New York City's Central Park. - Ecosystem Services 19: 87-91.

[80] Tidball, K. G., Krasny, M. E. (2011): Urban environmental education from a socialecological perspective: Conceptual framework for civic ecology education. - Cities and the Environment (CATE) 3: 11.

[81] Troy, A., Wilson, M. A. (2006): Mapping ecosystem services: practical challenges and opportunities in linking GIS and value transfer. - Ecological Economics 60: 435-449.

[82] United-Nations, D. O. E. a. S. A. (2014): World Urbanization Prospects: The 2014 Revision, Highlights. Department of Economic and Social Affairs. - Population Division, United Nations, New York.

[83] Van Heezik, Y., Freeman, C., Porter, S., Dickinson, K. J. (2013): Garden size, householder knowledge, and socio-economic status influence plant and bird diversity at the scale of individual gardens. - Ecosystems 16: 1442-1454.

[84] Vemuri, A. W., Costanza, R. (2006): The role of human, social, built, and natural capital in explaining life satisfaction at the country level: Toward a National Well-Being Index (NWI). - Ecological Economics 58: 119-133.

[85] Vollmer, D., Prescott, M. F., Padawangi, R., Girot, C., Grêt-Regamey, A. (2015): Understanding the value of urban riparian corridors: considerations in planning for cultural services along an Indonesian river. - Landscape and Urban Planning 138: 144-154.

[86] Wamsler, C., Brink, E., Rivera, C. (2013): Planning for climate change in urban areas: from theory to practice. - Journal of Cleaner Production 50: 68-81.

[87] Ward Thompson, C., Aspinall, P., Bell, S., Findlay, C. (2005): "It gets you away from everyday life": Local woodlands and community use-What makes a difference? Landscape Research 30: 109-146.

\section{APPENDIX}

Appendix 1. Questionnaire

\begin{tabular}{|l|l|l|}
\hline Date & \multicolumn{2}{|c|}{ GPS Coordinates } \\
\hline \multirow{2}{*}{} & LAT. & LONG. \\
\cline { 2 - 3 } & & \\
\hline
\end{tabular}

\begin{tabular}{|l|l|l|}
\hline 1 & \multirow{2}{*}{ Location of respondent } & (a) Islamabad \\
\hline 2 & Year of birth & (b) Rawalpindi \\
\hline 3 & Gender & (a) Male \\
\hline 4 & Highest education level & (b) Female \\
\hline 5 & Monthly household income & \\
\hline 6 & Do you have any knowledge about ecosystem? & Yes \\
\hline & & No \\
\hline 7 & What is the ownership status of your Dwelling? & (a) Personal \\
\hline & & (b) Official \\
\hline & & (c) Rented \\
\hline & & (e) andoted \\
\hline
\end{tabular}




\begin{tabular}{|c|c|c|}
\hline \multirow{5}{*}{8} & \multirow{5}{*}{$\begin{array}{l}\text { Do you think that urban vegetative cover is } \\
\text { beneficial for urban residents? }\end{array}$} & (a) Strongly disagree \\
\hline & & (b) Disagree \\
\hline & & (c) Agree \\
\hline & & (d) Strongly agree \\
\hline & & (e) Don’t know \\
\hline \multirow{5}{*}{9} & \multirow{5}{*}{$\begin{array}{l}\text { In your opinion, have the vegetative cover between } \\
\text { your work place and home have changed in the past } \\
10 \text { years? }\end{array}$} & (a) Strongly disagree \\
\hline & & (b) Disagree \\
\hline & & (c) Agree \\
\hline & & (d) Strongly agree \\
\hline & & (e) Don't know \\
\hline \multirow{3}{*}{10} & \multirow{3}{*}{$\begin{array}{l}\text { What is your opinion about the impacts of these } \\
\text { changes in vegetative cover? }\end{array}$} & (a) Positive change \\
\hline & & (b) Negative change \\
\hline & & (c) Don't know \\
\hline
\end{tabular}

Appendix 2. Latitude/longitude coordinates of the respondents

\begin{tabular}{|c|c|c|c|c|c|c|c|c|c|c|c|}
\hline Sr\# & LOC & LAT & LOG & Sr\# & LOC & LAT & LOG & Sr\# & LOC & LAT & LOG \\
\hline 1 & ISB & 33.536923 & 73.174316 & 26 & ISB & 33.639852 & 73.15182 & 51 & ISB & 33.672661 & 73.076228 \\
\hline 2 & ISB & 33.536846 & 73.172665 & 27 & ISB & 33.686116 & 72.99567 & 52 & ISB & 33.667629 & 73.066207 \\
\hline 3 & ISB & 33.63617 & 72.978908 & 28 & ISB & 33.658383 & 73.156036 & 53 & ISB & 33.649446 & 73.029046 \\
\hline 4 & ISB & 33.607847 & 72.850839 & 29 & ISB & 33.674268 & 73.064078 & 54 & ISB & 33.64249 & 73.033104 \\
\hline 5 & ISB & 33.530552 & 73.153841 & 30 & ISB & 33.725245 & 73.043077 & 55 & ISB & 33.664002 & 73.073039 \\
\hline 6 & ISB & 33.674121 & 73.140556 & 31 & ISB & 33.695646 & 73.059183 & 56 & ISB & 33.628747 & 72.970096 \\
\hline 7 & ISB & 33.672931 & 73.141064 & 32 & ISB & 33.711004 & 73.047149 & 57 & ISB & 33.635737 & 72.973216 \\
\hline 8 & ISB & 33.67256 & 73.141703 & 33 & ISB & 33.663343 & 72.997037 & 58 & ISB & 33.637068 & 72.973638 \\
\hline 9 & ISB & 33.671609 & 73.14178 & 34 & ISB & 33.680973 & 73.034108 & 59 & ISB & 33.630741 & 72.972535 \\
\hline 10 & ISB & 33.671251 & 73.14158 & 35 & ISB & 33.689797 & 73.025659 & 60 & ISB & 33.647733 & 73.031731 \\
\hline 11 & ISB & 33.727595 & 73.056729 & 36 & ISB & 33.700229 & 73.05811 & 61 & ISB & 33.634999 & 73.016013 \\
\hline 12 & ISB & 33.702391 & 72.973088 & 37 & ISB & 33.736223 & 73.18053 & 62 & ISB & 33.701716 & 72.977988 \\
\hline 13 & ISB & 33.726474 & 73.056701 & 38 & ISB & 33.714305 & 73.022111 & 63 & ISB & 33.626205 & 72.943854 \\
\hline 14 & ISB & 33.696425 & 73.002886 & 39 & ISB & 33.67777 & 73.006601 & 64 & ISB & 33.679226 & 73.006626 \\
\hline 15 & ISB & 33.718631 & 73.03959 & 40 & ISB & 33.70351 & 73.052849 & 65 & ISB & 33.68595 & 73.042524 \\
\hline 16 & ISB & 33.714255 & 73.030288 & 41 & ISB & 33.706771 & 73.057767 & 66 & ISB & 33.671719 & 73.138991 \\
\hline 17 & ISB & 33.714187 & 73.035895 & 42 & ISB & 33.670639 & 73.011922 & 67 & ISB & 33.67251 & 72.993287 \\
\hline 18 & ISB & $\mathbf{3 3 . 7 0 9 3 1 8}$ & 73.047175 & 43 & ISB & 33.659214 & 73.046819 & 68 & ISB & 33.656493 & 73.059137 \\
\hline 19 & ISB & 33.712017 & 73.032955 & 44 & ISB & 33.669774 & 72.989071 & 69 & ISB & 33.669039 & 72.992042 \\
\hline 20 & ISB & 33.657152 & 73.156284 & 45 & ISB & 33.645494 & 73.112561 & 70 & ISB & 33.694461 & 73.045402 \\
\hline 21 & ISB & 33.654241 & 73.153504 & 46 & ISB & 33.721724 & 73.035479 & 71 & ISB & 33.694822 & 73.032598 \\
\hline 22 & ISB & 33.641731 & 73.153008 & 47 & ISB & 33.699268 & 73.069618 & 72 & ISB & 33.697278 & 72.948379 \\
\hline 23 & ISB & 33.641161 & 73.151337 & 48 & ISB & 33.569066 & 73.146967 & 73 & ISB & 33.647354 & 73.038753 \\
\hline 24 & ISB & 33.640303 & 73.154155 & 49 & ISB & 33.722568 & 73.039925 & 74 & ISB & 33.655301 & 72.852578 \\
\hline 25 & ISB & 33.738727 & 73.184161 & 50 & ISB & 33.672295 & 73.032692 & 75 & ISB & 33.670407 & 73.033975 \\
\hline 76 & ISB & 33.680982 & 72.979134 & 101 & ISB & 33.710882 & 73.045141 & 126 & ISB & 33.707578 & 73.085324 \\
\hline 77 & ISB & 33.69022 & 72.978645 & 102 & ISB & 33.720249 & 73.061964 & 127 & ISB & 33.708621 & 73.088182 \\
\hline 78 & ISB & 33.620439 & 72.996606 & 103 & ISB & 33.657195 & 73.157919 & 128 & ISB & 33.708703 & 73.083634 \\
\hline 79 & ISB & 33.691769 & 72.999643 & 104 & ISB & 33.686878 & 73.004887 & 129 & ISB & 33.706632 & 73.082528 \\
\hline 80 & ISB & 33.670827 & 72.948749 & 105 & ISB & 33.718432 & 73.080917 & 130 & ISB & 33.706717 & 73.043412 \\
\hline 81 & ISB & 33.695233 & 72.976793 & 106 & ISB & 33.733158 & 73.174369 & 131 & ISB & 33.710411 & 73.080945 \\
\hline 82 & ISB & 33.539643 & 73.095454 & 107 & ISB & 33.664736 & 73.002125 & 132 & ISB & 33.700287 & 73.072771 \\
\hline 83 & ISB & 33.570388 & 73.117425 & 108 & ISB & 33.672513 & 73.015797 & 133 & ISB & 33.698098 & 73.067043 \\
\hline 84 & ISB & 33.618189 & 73.141211 & 109 & ISB & 33.665239 & 73.001066 & 134 & ISB & 33.710545 & 73.083518 \\
\hline 85 & ISB & 33.618473 & 73.140682 & 110 & ISB & 33.685229 & 73.027236 & 135 & ISB & 33.702063 & 73.06734 \\
\hline 86 & ISB & 33.668057 & 73.076849 & 111 & ISB & 33.710437 & 73.071021 & 136 & ISB & 33.700811 & 73.07123 \\
\hline 87 & ISB & 33.646749 & 73.102839 & 112 & ISB & 33.70951 & 73.048247 & 137 & ISB & 33.705475 & 73.035411 \\
\hline 88 & ISB & 33.658427 & 73.106216 & 113 & ISB & 33.682738 & 73.215079 & 138 & ISB & 33.495701 & 73.108808 \\
\hline 89 & ISB & 33.64129 & 72.95239 & 114 & ISB & 33.692377 & 73.056488 & 139 & ISB & 33.71154 & 73.049321 \\
\hline 90 & ISB & 33.70373 & 73.066209 & 115 & ISB & 33.62327 & 72.943758 & 140 & ISB & 33.708969 & 73.062294 \\
\hline 91 & ISB & 33.670355 & 73.138939 & 116 & ISB & 33.695217 & 72.986642 & 141 & ISB & 33.557094 & 73.162729 \\
\hline 92 & ISB & 33.671886 & 73.071259 & 117 & ISB & 33.673274 & 73.009671 & 142 & ISB & 33.556691 & 73.16306 \\
\hline 93 & ISB & 33.671893 & 73.139966 & 118 & ISB & 33.679621 & 72.980374 & 143 & ISB & 33.623932 & 73.012788 \\
\hline 94 & ISB & 33.679005 & 73.024874 & 119 & ISB & 33.698752 & 73.062879 & 144 & ISB & 33.643816 & 73.164535 \\
\hline 95 & ISB & 33.724127 & 73.03138 & 120 & ISB & 33.626269 & 72.938704 & 145 & ISB & 33.690077 & 73.132412 \\
\hline 96 & ISB & 33.631234 & 72.924653 & 121 & ISB & 33.668952 & 73.064887 & 146 & ISB & 33.689706 & 73.134008 \\
\hline 97 & ISB & 33.611977 & 73.132363 & 122 & ISB & 33.695896 & 73.049999 & 147 & ISB & 33.619684 & 73.232303 \\
\hline
\end{tabular}




\begin{tabular}{|c|c|c|c|c|c|c|c|c|c|c|c|}
\hline Sr\# & LOC & LAT & LOG & Sr\# & LOC & LAT & LOG & Sr\# & LOC & LAT & LOG \\
\hline 98 & ISB & 33.699753 & 72.984497 & 123 & ISB & 33.699589 & 73.057207 & 148 & ISB & 33.622834 & 72.946026 \\
\hline 99 & ISB & 33.705505 & 73.068856 & 124 & ISB & 33.692888 & 73.037481 & 149 & ISB & 33.622654 & 72.950913 \\
\hline 100 & ISB & 33.721313 & 73.059746 & 125 & ISB & 33.712002 & 73.083751 & 150 & ISB & 33.621713 & 72.953511 \\
\hline 151 & ISB & $\mathbf{3 3 . 6 2 4 3 7 7}$ & 72.945877 & 176 & ISB & 33.72393 & 73.075909 & 201 & ISB & 33.652231 & \\
\hline 152 & ISB & 33.624294 & 72.9349 & 177 & ISB & 33.624144 & 72.994379 & 202 & ISB & 33.694964 & $\begin{array}{l}73.037178 \\
\end{array}$ \\
\hline 153 & ISB & 33.622098 & 72.939162 & 178 & ISB & 33.671857 & 73.14728 & 203 & ISB & 33.694515 & 73.038306 \\
\hline 154 & ISB & 33.627738 & 72.939469 & 179 & ISB & 33.675006 & 73.140656 & 204 & ISB & 33.690772 & 73.013949 \\
\hline 155 & ISB & 33.746165 & 73.108932 & 180 & ISB & 33.657607 & 73.263599 & 205 & ISB & 33.66934 & 73.140189 \\
\hline 156 & ISB & 33.631731 & 73.12582 & 181 & ISB & 33.672902 & 73.074871 & 206 & ISB & 33.69016 & 72.999606 \\
\hline 157 & ISB & 33.648742 & 73.030719 & 182 & ISB & 33.700907 & 72.975272 & 207 & ISB & 33.690384 & 73.001077 \\
\hline 158 & ISB & 33.672778 & 73.01 & 183 & ISB & 33.661296 & 73.069463 & 208 & ISB & & \\
\hline 159 & ISB & 33.654015 & 73.05 & 184 & ISB & 33.714659 & 73.16226 & 209 & ISB & 33.578604 & 73.139552 \\
\hline 160 & ISB & 33.704869 & 73.07659 & 185 & ISB & 33.639195 & 73.149173 & 210 & ISB & & \\
\hline 161 & ISB & 33.702552 & 73.060185 & 186 & ISB & 33.639918 & 72.950984 & 211 & ISB & & 73.03381 \\
\hline 162 & ISB & 33.651859 & 73.050697 & 187 & ISB & 33.669746 & 73.154194 & 212 & ISB & 33.700223 & 72.982942 \\
\hline 163 & ISB & 33.705539 & 73.060612 & 188 & ISB & 33.674283 & 73.142104 & 213 & ISB & 33.677745 & 72.988324 \\
\hline 164 & ISB & & 73.0 & 189 & ISB & & 386 & 214 & ISB & & \\
\hline 165 & ISB & & 73.0 & 190 & ISB & 929 & 0774 & 215 & ISB & & \\
\hline 166 & ISB & & 72.9 & 191 & ISB & 326 & 73.1 & 216 & ISB & & \\
\hline 167 & ISB & & 73.0. & 192 & ISB & & 4669 & 217 & ISB & & \\
\hline 168 & ISB & 33.68 & 73.0 & 193 & ISB & & 73.1 & 218 & ISB & & \\
\hline 169 & ISB & 33.686034 & 73.044555 & 194 & ISB & 33.67168 & 72.988695 & 219 & ISB & \begin{tabular}{|c|}
33.717299 \\
\end{tabular} & 73.099787 \\
\hline 170 & ISB & 33.66543 & 73.04874 & 195 & ISB & 33.646963 & 73.169625 & 220 & ISB & & 72.922582 \\
\hline 171 & ISB & & 73. & 196 & ISB & & & 221 & ISB & & \\
\hline 172 & ISB & & 73.0 & 197 & ISB & & 73. & 222 & ISB & & \\
\hline 173 & ISB & & 73.0 & 198 & ISB & & 73.0 & 223 & ISB & & 029 \\
\hline 174 & ISB & & 73.0 & 199 & ISB & & 73. & 224 & ISB & & \\
\hline 175 & ISB & 33.6 & 73.0 & 200 & ISB & & 73.0 & 225 & ISB & & \\
\hline 226 & ISB & 33.68 & 73.01 & 251 & RWP & & 73.052939 & 276 & RWP & & 72.994807 \\
\hline 227 & ISB & & $\mathbf{7 3 . 0}$ & 252 & RWP & & & 277 & RWP & & \\
\hline 228 & ISB & & & 253 & RWP & & & 278 & RWP & & \\
\hline 229 & ISB & & 73.0 & 254 & RWP & & 467 & 279 & RWP & & \\
\hline 230 & ISB & & & 255 & RWP & & 948 & 280 & RWP & & \\
\hline 231 & ISB & & 73.0 & 256 & RWP & & 716 & 281 & RWP & & \\
\hline 232 & ISB & & 72.919074 & 257 & RWP & 5075 & 73.072464 & 282 & RWP & & 73.094389 \\
\hline 233 & ISB & & 72.918588 & 258 & RWP & 33.644763 & 73.059759 & 283 & RWP & & 72.989813 \\
\hline 234 & ISB & & & 259 & RWP & & & 284 & RWP & & \\
\hline 235 & ISB & & 72.9 & 260 & RWP & & 72. & 285 & RWP & & \\
\hline 236 & ISB & & 73.0 & 261 & RWP & & 549 & 286 & RWP & 722 & \\
\hline 237 & ISB & & & 262 & RWP & & & 287 & RWP & & 388 \\
\hline 238 & ISB & 4066 & 72.965343 & 263 & RWP & 33.564942 & 7254 & 288 & RWP & 33.526769 & 73.048802 \\
\hline 239 & ISB & 33.647732 & 72.960076 & 264 & RWP & 33.580883 & 2126 & 289 & RWP & 33.630557 & 73.091877 \\
\hline 240 & ISB & & & 265 & RWP & 33.580648 & 1418 & 290 & RWP & & 73.107934 \\
\hline 241 & ISB & & & 266 & RWP & & & 291 & RWP & & \\
\hline 242 & ISB & & 72.9 & 267 & RWP & & & 292 & RWP & & \\
\hline 243 & ISB & & & 268 & RWP & & & 293 & RWP & & \\
\hline 244 & ISB & & & 269 & RWP & & 73.112299 & 294 & RWP & 33.626592 & \\
\hline 245 & ISB & 33.666143 & 73.069079 & 270 & RWP & 33.496669 & 73.110121 & 295 & RWP & 33.497421 & 73.047907 \\
\hline 246 & ISB & 33.72704 & 73.048121 & 271 & RWP & 33.583832 & 73.017894 & 296 & RWP & 33.62862 & 73.085249 \\
\hline 247 & ISB & & & 272 & RWP & & 73.129152 & 297 & RWP & & 73.086797 \\
\hline 248 & ISB & & & 273 & RWP & & & 298 & RWP & & \\
\hline 249 & ISB & & & 274 & RWP & & & 299 & RWP & & \\
\hline 250 & ISB & & & 275 & RWP & & & 300 & RWP & & \\
\hline 301 & RWP & & 7 & 326 & RWP & & 73.066494 & 351 & RWP & 625679 & 355 \\
\hline 302 & RWP & 33.6 & 72.990838 & 327 & RWP & $\mathbf{3 3 . 6 1 8 4 0 7}$ & 73.039625 & 352 & RWP & 33.628053 & 73.091542 \\
\hline 303 & RWP & 33.553054 & 73.009223 & 328 & RWP & 33.618459 & 73.040014 & 353 & RWP & 33.583316 & 73.016337 \\
\hline 304 & RWP & & & 329 & RWP & & 73.039326 & 354 & RWP & 33.583413 & 73.016256 \\
\hline 305 & RWP & & & 330 & RWP & & & 355 & RWP & & 89765 \\
\hline 306 & RWP & & & 331 & RWP & & & 356 & RWP & 758 & \\
\hline 307 & RWP & & 22 & 332 & RWP & & 2289 & 357 & RWP & 33.61356 & 73.007475 \\
\hline 308 & RWP & & & 333 & RWP & & & 358 & RWP & & \\
\hline 309 & RWP & 33.560568 & 73.0614 & 334 & RWP & & $\begin{array}{l}73.045308 \\
\end{array}$ & 359 & RWP & \begin{tabular}{|c|}
33.604799 \\
\end{tabular} & 73.058725 \\
\hline 310 & RWP & 33.560904 & 73.061845 & 335 & RWP & 33.612488 & 73.045125 & 360 & RWP & 33.605096 & 73.058758 \\
\hline 311 & RWP & 33.561933 & $\begin{array}{l}73.062401 \\
\end{array}$ & 336 & RWP & 33.621739 & 73.040206 & 361 & RWP & 33.564843 & 72.99385 \\
\hline 312 & RWP & 33.600164 & 73.033664 & 337 & RWP & 33.650872 & 73.073036 & 362 & RWP & 33.556354 & \\
\hline 313 & RWP & 33.561977 & 73.061278 & 338 & RWP & 33.651427 & 73.072265 & 363 & RWP & 33.557308 & 73.012867 \\
\hline 314 & RWP & & & 339 & RWP & & 73.098715 & 364 & RWP & & \\
\hline 315 & RWP & 33.572637 & 73.038673 & 340 & RWP & & 73.102621 & 365 & RWP & 33.621521 & 73.037754 \\
\hline
\end{tabular}




\begin{tabular}{|c|c|c|c|c|c|c|c|c|c|c|c|}
\hline Sr\# & LOC & LAT & LOG & Sr\# & LOC & LAT & LOG & Sr\# & LOC & LAT & LOG \\
\hline 316 & RWP & 33.566926 & 73.030336 & 341 & RWP & 33.621525 & 73.060629 & 366 & RWP & 33.631609 & 73.06565 \\
\hline 317 & RWP & 33.544268 & 73.067471 & 342 & RWP & 33.621457 & 73.061821 & 367 & RWP & 33.597469 & 73.069398 \\
\hline 318 & RWP & 33.486988 & 73.099908 & 343 & RWP & 33.607402 & 73.00942 & 368 & RWP & 33.597341 & 73.071352 \\
\hline 319 & RWP & 33.58562 & 73.091711 & 344 & RWP & 33.584748 & 73.027598 & 369 & RWP & 33.600499 & 73.050567 \\
\hline 320 & RWP & 33.608074 & 73.04495 & 345 & RWP & 33.585021 & 73.03487 & 370 & RWP & 33.62114 & 72.980886 \\
\hline 321 & RWP & 33.591667 & 73.046588 & 346 & RWP & $\mathbf{3 3 . 6 1 4 5 9 7}$ & 73.00681 & 371 & RWP & 33.582371 & 73.09762 \\
\hline 322 & RWP & 33.616621 & 73.065852 & 347 & RWP & 33.550436 & 73.115782 & 372 & RWP & 33.583582 & 73.095847 \\
\hline 323 & RWP & 33.616167 & \begin{tabular}{|c|}
73.065788 \\
\end{tabular} & 348 & RWP & $\mathbf{3 3 . 5 3 0 0 7 7}$ & 73.112428 & 373 & RWP & 33.641394 & 73.068788 \\
\hline 324 & RWP & 33.596916 & $\mathbf{7 3 . 0 5 3 8 5 7}$ & 349 & RWP & 33.596473 & 73.022209 & 374 & RWP & 33.638368 & 73.056437 \\
\hline 325 & RWP & 33.616496 & 73.06608 & 350 & RWP & 33.596454 & 73.019341 & 375 & RWP & 33.635115 & 73.085288 \\
\hline 376 & RWP & 33.544563 & 73.055324 & 401 & RWP & 33.624667 & \begin{tabular}{|l|}
73.054338 \\
\end{tabular} & 426 & RWP & 33.557562 & 73.061322 \\
\hline 377 & RWP & 33.625636 & 73.064122 & 402 & RWP & 33.652706 & 73.07189 & 427 & RWP & 33.589325 & 73.025251 \\
\hline 378 & RWP & 33.642315 & 73.081253 & 403 & RWP & 33.607978 & 73.066514 & 428 & RWP & 33.628171 & 73.124221 \\
\hline 379 & RWP & 33.551925 & 73.027701 & 404 & RWP & 33.625575 & 73.075722 & 429 & RWP & 33.596572 & 73.024144 \\
\hline 380 & RWP & 33.552281 & 73.013677 & 405 & RWP & 33.628529 & 73.109527 & 430 & RWP & 33.596275 & 73.025553 \\
\hline 381 & RWP & 33.634119 & 73.090047 & 406 & RWP & 33.582073 & 73.019416 & 431 & RWP & 33.594028 & 73.130073 \\
\hline 382 & RWP & $\mathbf{3 3 . 5 9 4 4 7 7}$ & 73.02448 & 407 & RWP & 33.603771 & 73.008261 & 432 & RWP & 33.621935 & 73.041589 \\
\hline 383 & RWP & 33.5936 & 73.021246 & 408 & RWP & 33.626628 & \begin{tabular}{|l|l}
73.017598 \\
\end{tabular} & 433 & RWP & 33.586621 & 73.078158 \\
\hline 384 & RWP & 33.651597 & 73.065626 & 409 & RWP & 33.62701 & 73.032636 & 434 & RWP & 33.605451 & 73.093072 \\
\hline 385 & RWP & 33.627663 & 73.057469 & 410 & RWP & 33.622498 & 73.011807 & 435 & RWP & 33.598654 & 73.026315 \\
\hline 386 & RWP & 33.652161 & 73.090715 & 411 & RWP & 33.626204 & 73.064411 & 436 & RWP & $\mathbf{3 3 . 6 0 5 2 5 7}$ & 73.091759 \\
\hline 387 & RWP & 33.65293 & 73.091171 & 412 & RWP & 33.594171 & 73.126695 & 437 & RWP & 33.58513 & 73.088427 \\
\hline 388 & RWP & 33.496017 & 73.110314 & 413 & RWP & 33.59433 & 73.126932 & 438 & RWP & 33.614625 & 73.02527 \\
\hline 389 & RWP & 33.49659 & 73.108891 & 414 & RWP & 33.637067 & 73.077261 & 439 & RWP & 33.596077 & 73.134311 \\
\hline 390 & RWP & 33.63229 & 73.038046 & 415 & RWP & 33.593028 & 73.130417 & 440 & RWP & 33.626994 & 73.094579 \\
\hline 391 & RWP & 33.633104 & $\mathbf{7 3 . 0 3 7 9 5}$ & 416 & RWP & 33.637044 & 73.069514 & 441 & RWP & 33.616851 & 73.062575 \\
\hline 392 & RWP & 33.633113 & 73.037213 & 417 & RWP & 33.590299 & 73.132788 & 442 & RWP & 33.522612 & 73.048165 \\
\hline 393 & RWP & $\mathbf{3 3 . 5 6 8 3 7 7}$ & 73.052454 & 418 & RWP & 33.629281 & 73.092291 & 443 & RWP & 33.474636 & 73.014316 \\
\hline 394 & RWP & 33.567956 & 73.052714 & 419 & RWP & 33.628574 & 73.060012 & 444 & RWP & $\mathbf{3 3 . 5 8 3 4 7 7}$ & 73.024615 \\
\hline 395 & RWP & 33.633629 & 73.07574 & 420 & RWP & $\mathbf{3 3 . 5 9 8 2 8 5}$ & 72.994212 & 445 & RWP & 33.62893 & 73.116726 \\
\hline 396 & RWP & 33.616649 & 72.990835 & 421 & RWP & 33.552195 & 73.119747 & 446 & RWP & 33.651335 & 73.064304 \\
\hline 397 & RWP & 33.617502 & 72.991409 & 422 & RWP & 33.607463 & 73.09511 & 447 & RWP & 33.635075 & 73.038575 \\
\hline 398 & RWP & 33.618942 & 73.079751 & 423 & RWP & 33.599097 & 73.015775 & 448 & RWP & 33.634102 & 73.063326 \\
\hline 399 & RWP & 33.58213 & $\begin{array}{l}73.03863 \\
\end{array}$ & 424 & RWP & 33.629861 & 73.090781 & 449 & RWP & 33.620943 & 73.051603 \\
\hline 400 & RWP & 33.581969 & 73.039268 & 425 & RWP & 33.654378 & 73.071851 & 450 & RWP & 33.634531 & 73.069006 \\
\hline 451 & RWP & 33.622218 & 73.050947 & 476 & RWP & 33.615132 & 73.046074 & & & & \\
\hline 452 & RWP & 33.633956 & 73.069073 & 477 & RWP & 33.6 & 73.039156 & & & & \\
\hline 453 & RWP & 33.63611 & 73.076866 & 478 & RWP & 33.652163 & 73.082399 & & & & \\
\hline 454 & RWP & 33.627316 & 72.941757 & 479 & RWP & 33.617326 & 73.030224 & & & & \\
\hline 455 & RWP & 33.61338 & 72.991244 & 480 & RWP & 33.605947 & 73.008537 & & & & \\
\hline 456 & RWP & 33.602171 & 73.000066 & 481 & RWP & 33.616002 & 73.043123 & & & & \\
\hline 457 & RWP & 33.619449 & 72.997178 & 482 & RWP & \begin{tabular}{|c|}
3.647004 \\
\end{tabular} & 73.058734 & & & & \\
\hline 458 & RWP & 33.617075 & 72.987958 & 483 & RWP & 33.64691 & 73.061459 & & & & \\
\hline 459 & RWP & 33.623411 & 72.983935 & 484 & RWP & 33.598928 & 73.049117 & & & & \\
\hline 460 & RWP & 33.60239 & 73.018763 & 485 & RWP & $\mathbf{3 3 . 5 9 6 7 3 7}$ & 73.044823 & & & & \\
\hline 461 & RWP & 33.619696 & 73.051036 & 486 & RWP & 33.631572 & 73.05052 & & & & \\
\hline 462 & RWP & 33.590859 & 73.074469 & 487 & RWP & 33.607581 & 73.006539 & & & & \\
\hline 463 & RWP & 33.628651 & 73.060912 & 488 & RWP & 33.611767 & 73.068567 & & & & \\
\hline 464 & RWP & 33.626496 & 73.035736 & 489 & RWP & $\mathbf{3 3 . 6 3 0 1 3 7}$ & 73.062296 & & & & \\
\hline 465 & RWP & 33.604472 & 73.074591 & 490 & RWP & 33.631233 & 73.061962 & & & & \\
\hline 466 & RWP & 33.62491 & 73.03405 & 491 & RWP & 33.639587 & 73.049848 & & & & \\
\hline 467 & RWP & 33.596699 & 73.012665 & 492 & RWP & 33.621038 & 73.064693 & & & & \\
\hline 468 & RWP & 33.62567 & 73.031908 & 493 & RWP & 33.620015 & 73.077435 & & & & \\
\hline 469 & RWP & 33.604092 & 73.072392 & 494 & RWP & 33.364216 & 73.15347 & & & & \\
\hline 470 & RWP & 33.62645 & 73.03099 & 495 & RWP & 33.37426 & 73.222 & & & & \\
\hline 471 & RWP & $\mathbf{3 3 . 5 8 8 1 4 7}$ & 73.025732 & 496 & RWP & 33.363432 & 73.25764 & & & & \\
\hline 472 & RWP & 33.627691 & 73.084004 & 497 & RWP & 33.3752 & 73.24996 & & & & \\
\hline 473 & RWP & 33.536371 & 73.079054 & 498 & RWP & 33.36576 & $\begin{array}{l}73.4368 \\
\end{array}$ & & & & \\
\hline 474 & RWP & 33.6254 & 73.050937 & 499 & RWP & 33.364445 & 73.43563 & & & & \\
\hline 475 & RWP & 33.586415 & 73.023293 & 500 & RWP & 33.374917 & 73.43779 & & & & \\
\hline
\end{tabular}


Atif et al:: The impacts of socio-economic factors on the perception of residents about urban vegetation: a comparative study of planned versus semi-planned cities of Islamabad and Rawalpindi, Pakistan $-4285-$

Appendix 3. The socio-economic and demographic characteristics of respondents and their predilections

\begin{tabular}{|c|c|c|c|c|c|c|c|c|c|c|c|c|c|c|c|c|c|c|}
\hline \multirow{2}{*}{$\begin{array}{l}\rightarrow \\
\stackrel{ \pm}{ \pm}\end{array}$} & \multirow{2}{*}{$\begin{array}{c}\text { City code } \\
\downarrow\end{array}$} & \multirow{2}{*}{$\begin{array}{c}\text { Predictor } \\
\text { Categories } \\
\downarrow\end{array}$} & \multicolumn{7}{|c|}{$\begin{array}{l}\text { Natural capital beneficial for } \\
\text { urban residents? }\end{array}$} & \multicolumn{6}{|c|}{ Did vegetation cover change? } & \multicolumn{3}{|c|}{ Change type? } \\
\hline & & & ST.AG & AG & & VL & DA & & T.DA & ST.AG & AG & & NL & DA & ST.DA & - ve & +ve & NA \\
\hline \multirow{2}{*}{ : } & - & Islamabad & $7^{99}$ & 13 & & 9 & & & & 38 & 14 & & 40 & 15 & 14 & 126 & 82 & 42 \\
\hline & $\simeq$ & Rawalpindi & 78 & $\overline{14}$ & & 17 & & & & 20 & 14 & & 50 & 24 & 11 & $\overline{153}$ & 53 & 44 \\
\hline \multirow{4}{*}{ 这 } & & FEMALE & 24 & $\overline{4}$ & & 3 & & & 2 & 13 & & & 12 & 3 & 5 & 27 & 29 & 15 \\
\hline & 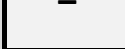 & MALE & $7^{75}$ & 9 & & 6 & & & 2 & 25 & & & 28 & 12 & 9 & $\overline{99}$ & 53 & 27 \\
\hline & $\alpha$ & FEMALE & 22 & 4 & & 6 & & & 3 & 7 & & & 18 & 6 & 3 & 40 & 20 & 17 \\
\hline & 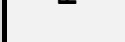 & MALE & 56 & $\overline{9}$ & & 11 & & & 2 & 13 & $\overline{10}$ & & 32 & 18 & 8 & $\overline{113}$ & 33 & 27 \\
\hline \multirow{10}{*}{ 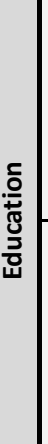 } & & 1.UE & 1 & 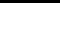 & & 1 & & & 0 & 1 & & & 1 & 0 & 0 & 2 & 1 & 0 \\
\hline & & 2.MT & 4 & 1 & & 3 & & & & 3 & & & 4 & 1 & 2 & 11 & 6 & \\
\hline & - & $3 . G R$ & 24 & 3 & & 2 & & & 2 & 9 & & & 13 & 8 & 6 & 24 & 33 & 13 \\
\hline & & 4.PG & 53 & $\overline{6}$ & & 3 & & & & 22 & 7 & & 17 & 5 & 4 & $\overline{70}$ & 33 & 17 \\
\hline & & 5.PD & 17 & 1 & & 0 & & & 0 & 3 & 2 & & 5 & 1 & 2 & 19 & 9 & 5 \\
\hline & & 1.UE & 0 & 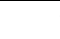 & & 1 & & & & 0 & & & 3 & 1 & 0 & 3 & 1 & 3 \\
\hline & & 2.MT & & 4 & & 5 & & & 2 & 1 & & & 14 & 8 & 2 & 35 & 12 & 13 \\
\hline & $\simeq$ & 3.GR & 32 & $\sqrt{4}$ & & 7 & & & 2 & 6 & & & 18 & 5 & 4 & 55 & 18 & 16 \\
\hline & & 4.PG & 35 & $7^{4}$ & & 4 & & & 0 & 13 & 4 & & 14 & 9 & 5 & 54 & 21 & 10 \\
\hline & & 5.PD & $\sqrt[3]{4}$ & 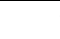 & & 0 & & & 0 & 0 & 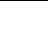 & & 1 & 1 & 0 & 6 & 1 & 2 \\
\hline \multirow{10}{*}{ 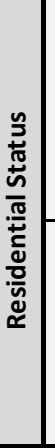 } & & 1.ALT & 6 & r & & 0 & & & 0 & 2 & & & 3 & & 0 & 5 & 2 & 2 \\
\hline & & 2.GOV & ${ }^{10}$ & 1 & & 0 & & & 0 & 3 & & & 4 & 1 & 0 & 13 & 11 & 3 \\
\hline & - & 3.PER & 50 & 7 & & 7 & & & 2 & 24 & $\overline{8}$ & & 15 & 10 & 7 & 767 & 50 & 19 \\
\hline & & 4.REN & 31 & 3 & & 2 & & & 2 & 7 & 4 & & 18 & 3 & 6 & 40 & 17 & 17 \\
\hline & & 5.0TH & 2 & 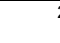 & & 0 & & & 0 & 2 & 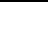 & & 0 & 0 & & 1 & 2 & \\
\hline & & 1.ALT & 1 & 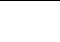 & & 0 & & & 0 & 1 & & & 0 & 0 & 0 & 1 & 1 & 0 \\
\hline & & 2.GOV & 2 & & & 2 & & & 0 & 0 & & & 2 & 0 & 0 & 4 & 1 & 3 \\
\hline & $\simeq$ & 3.PER & 50 & 9 & & 5 & & & 2 & 9 & $\overline{9}$ & & 27 & 16 & 3 & $\overline{95}$ & 32 & 24 \\
\hline & & 4.REN & 21 & 4 & & 10 & & & 3 & 9 & 3 & & 21 & 8 & 8 & 52 & 16 & 17 \\
\hline & & 5.ОTH & 4 & 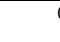 & & 0 & & & 0 & 1 & & & 0 & 0 & 0 & 1 & 3 & 0 \\
\hline \multirow{8}{*}{ 茂 } & & 1.A & ${ }^{3} \mid$ & 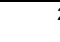 & & 0 & & & 0 & 1 & & & 1 & 0 & 0 & 4 & 2 & 0 \\
\hline & 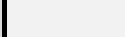 & 2.B & 37 & $\overline{5}$ & & 4 & & & 2 & 18 & & & 13 & 8 & 7 & $\sqrt{51}$ & 32 & 20 \\
\hline & & 3.C & 753 & 6 & & 5 & & & 2 & 19 & & & 22 & 6 & 7 & $\overline{67}$ & 41 & 17 \\
\hline & & 4.D & ${ }^{6}$ & s. & & 0 & & & 0 & 0 & & & 4 & & 0 & $\overline{4}$ & 7 & 5 \\
\hline & & 1.A & 1 & & & 3 & & & 0 & 1 & & & 2 & 0 & 1 & 3 & 0 & 2 \\
\hline & & 2.B & 40 & 7 & & 9 & & & 0 & 13 & $\overline{6}$ & & 27 & 15 & 8 & 71 & 28 & 27 \\
\hline & 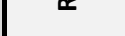 & 3.C & 29 & 5 & & 4 & & & 5 & 5 & & & 16 & 8 & 2 & $\overline{63}$ & 20 & 12 \\
\hline & & 4.D & 8 & 1 & & 1 & & & 0 & 1 & & & 5 & & 0 & 16 & 5 & 3 \\
\hline \multirow{10}{*}{ 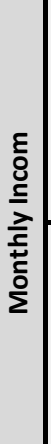 } & & C.1 & 6 & 2 & & 3 & & & & 4 & & & 11 & & 3 & $\overline{13}$ & 9 & 9 \\
\hline & & C. 2 & 18 & 3 & & 2 & & & & 4 & 4 & & 5 & 4 & 4 & 9 & 10 & 38 \\
\hline & - & C.3 & 15[ & 1 & & 1 & & & & 6 & & & 6 & 4 & 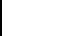 & 12 & 5 & 18 \\
\hline & & C. 4 & 28 & 2 & & 2 & & & & 11 & 3 & & 8 & 2 & 2 & 16 & 6 & 31 \\
\hline & & C. 5 & 32 & 3 & & 1 & & & & 13 & 4 & & \begin{tabular}{l|l|}
10 \\
\end{tabular} & 4 & 5 & 32 & 12 & 30 \\
\hline & & C.1 & 10 & $\sqrt{3}$ & & 6 & & & 2 & 2 & $\overline{2}$ & & 13 & 10 & 4 & 14 & 14 & 29 \\
\hline & & C. 2 & 33 & $\overline{7}$ & & 8 & & & 2 & 6 & 7 & & 25 & 8 & 4 & 20 & 20 & 73 \\
\hline & $\simeq$ & C. 3 & 12 & 2 & & 1 & & & & 6 & & & 5 & 3 & 1 & 5 & 5 & 26 \\
\hline & & C. 4 & & 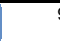 & & 2 & & & & 3 & & & 6 & & & 7 & 3 & 17 \\
\hline & & C.5 & & & & & & & & 3 & & & & & & & 2 & \\
\hline
\end{tabular}


Atif et al.: The impacts of socio-economic factors on the perception of residents about urban vegetation: a comparative study of planned versus semi-planned cities of Islamabad and Rawalpindi, Pakistan -4286 -

Appendix 4. Pair-wise findings of Wilcoxon Rank Sum Test (WRST) based upon predictor variables about Urban Vegetation is Beneficial for Residents (UVBR)

\begin{tabular}{|c|c|c|c|c|}
\hline \multicolumn{5}{|l|}{ a: Education } \\
\hline & Matric & Graduate & Postgraduate & Professional \\
\hline \multirow[t]{4}{*}{ Uneducated } & 0.449 & 0.039 & 0.006 & 0.014 \\
\hline & Matric & 0.0005 & 0.0000001 & 0.0001 \\
\hline & & Graduate & 0.055 & 0.144 \\
\hline & & & Postgraduate & 0.712 \\
\hline \multicolumn{5}{|c|}{ b: Residential Status } \\
\hline & Rented & Government & Allotted & Others \\
\hline \multirow[t]{4}{*}{ Personal } & 0.24 & 0.78 & 0.04 & 0.02 \\
\hline & Rented & 0.73 & 0.03 & 0.02 \\
\hline & & Government & 0.07 & 0.04 \\
\hline & & & Allotted & 0.64 \\
\hline \multicolumn{5}{|l|}{ c: Age } \\
\hline & \multicolumn{2}{|c|}{ up to 20 years } & 21 to 40 years & 41 to 60 years \\
\hline \multirow[t]{3}{*}{ 61years and above } & \multicolumn{2}{|c|}{0.001} & 0.0003 & 0.0002 \\
\hline & up to $20 \mathrm{ye}$ & & 0.452 & 0.67 \\
\hline & & & 21 to 40 years & 0.065 \\
\hline d: Monthly Income & & & & \\
\hline & Up to Rs. 25000 & $\begin{array}{l}\text { Rs. } 25001 \text { to } \\
50000\end{array}$ & $\begin{array}{l}\text { Rs.50001 to } \\
75000\end{array}$ & $\begin{array}{l}\text { Rs.75001 to } \\
100000\end{array}$ \\
\hline $\begin{array}{l}\text { Rs.100001 and } \\
\text { Above }\end{array}$ & 0.00001 & 0.015 & 0.378 & 0.374 \\
\hline & Up to Rs.25000 & 0.005 & 0.001 & 0.000003 \\
\hline & & $\begin{array}{l}\text { Rs. } 25001 \text { to } \\
50000\end{array}$ & 0.221 & 0.002 \\
\hline & & & $\begin{array}{l}\text { Rs.50001 to } \\
75000\end{array}$ & 0.106 \\
\hline
\end{tabular}

Appendix 5. Pair-wise findings of Wilcoxon Rank Sum Test (WRST) based upon predictor variables about Vegetation Cover Changes (VCC)

\begin{tabular}{|c|c|c|c|c|c|}
\hline \multicolumn{6}{|l|}{ a: Education } \\
\hline & Matric & \multicolumn{2}{|c|}{ Graduate } & Postgraduate & Professional \\
\hline \multirow[t]{4}{*}{ Uneducated } & 0.795 & \multicolumn{2}{|c|}{0.573} & 0.207 & 0.279 \\
\hline & \multirow[t]{2}{*}{ Matric } & \multicolumn{2}{|c|}{0.442} & 0.009 & 0.146 \\
\hline & & \multicolumn{2}{|c|}{ Graduate } & 0.029 & 0.381 \\
\hline & & & & Postgraduate & 0.554 \\
\hline \multicolumn{6}{|l|}{ b: Residential Status } \\
\hline & Rented & \multicolumn{2}{|c|}{ Government } & Allotted & Others \\
\hline \multirow[t]{4}{*}{ Personal } & 0.01 & \multicolumn{2}{|c|}{0.5} & 0.72 & 0.11 \\
\hline & Rented & \multicolumn{2}{|c|}{0.05} & 0.32 & 0.06 \\
\hline & & \multicolumn{2}{|c|}{ Government } & 0.98 & 0.15 \\
\hline & & & & Allotted & 0.48 \\
\hline \multicolumn{6}{|l|}{ c: Age } \\
\hline & \multicolumn{2}{|c|}{ up to 20 years } & \multicolumn{2}{|c|}{21 to 40 years } & 41 to 60 years \\
\hline \multirow[t]{2}{*}{ 61years and above } & \multicolumn{2}{|c|}{0.0002} & \multicolumn{2}{|c|}{0.00009} & 0.0002 \\
\hline & \multicolumn{2}{|c|}{ up to 20 years } & \multicolumn{2}{|c|}{0.9} & 0.6 \\
\hline
\end{tabular}




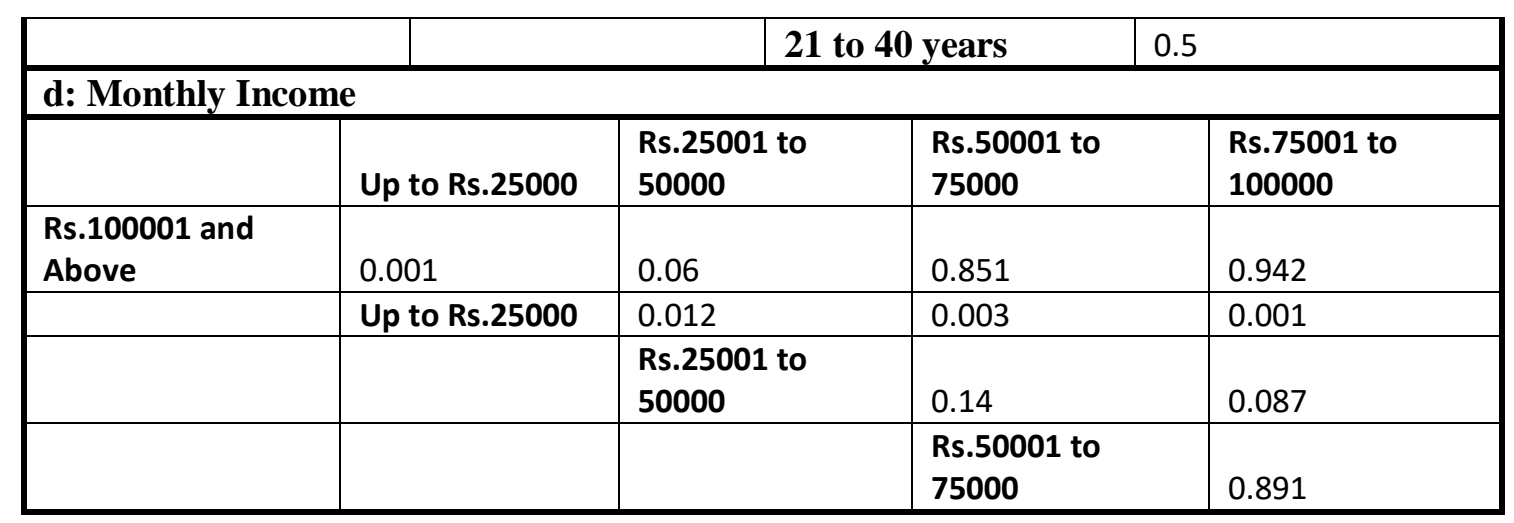

Appendix 6. Pair-wise findings of Wilcoxon Rank Sum Test (WRST) based upon predictor variables about Impacts of Changes in Urban Vegetation (ICUV)

\begin{tabular}{|c|c|c|c|c|c|}
\hline \multicolumn{6}{|l|}{ a: Gender } \\
\hline & & & \multicolumn{3}{|l|}{ FEMALE } \\
\hline & & MALE & \multicolumn{3}{|l|}{0.05} \\
\hline \multicolumn{6}{|l|}{ b: Education } \\
\hline & Matric & \multicolumn{2}{|l|}{ Graduate } & Postgraduate & Professional \\
\hline \multirow[t]{4}{*}{ Uneducated } & 0.87 & \multicolumn{2}{|l|}{0.039} & 0.006 & 0.014 \\
\hline & Matric & \multicolumn{2}{|l|}{0.22} & 0.73 & 0.79 \\
\hline & & \multicolumn{2}{|l|}{ Graduate } & 0.06 & 0.24 \\
\hline & & & & Postgraduate & 0.97 \\
\hline \multicolumn{6}{|c|}{ c: Residential Status } \\
\hline & Rented & \multicolumn{2}{|c|}{ Government } & Allotted & Others \\
\hline \multirow[t]{4}{*}{ Personal } & 0.31 & \multicolumn{2}{|c|}{0.4} & 0.97 & 0.05 \\
\hline & Rented & \multicolumn{2}{|l|}{0.16} & 0.72 & 0.02 \\
\hline & & \multicolumn{2}{|c|}{ Government } & 0.69 & 0.16 \\
\hline & & & & Allotted & 0.15 \\
\hline \multicolumn{6}{|l|}{ d: Age } \\
\hline & \multicolumn{2}{|c|}{ up to 20 years } & 21 to 40 & years & 41 to 60 years \\
\hline 61years and abov & 0.6 & & 1 & & 0.8 \\
\hline & up to $20 \mathrm{ye}$ & & 0.4 & & 0.7 \\
\hline & & & 21 to 40 & years & 0.5 \\
\hline e: Monthly Incon & & & & & \\
\hline & Up to Rs. 25000 & $\begin{array}{l}\text { Rs.25001 } \\
50000\end{array}$ & & $\begin{array}{l}\text { Rs.50001 to } \\
75000\end{array}$ & $\begin{array}{l}\text { Rs.75001 to } \\
100000\end{array}$ \\
\hline $\begin{array}{l}\text { Rs.100001 and } \\
\text { Above }\end{array}$ & 0.327 & 0.00002 & & 0.007 & 0.021 \\
\hline & Up to Rs. 25000 & 0.0006 & & 0.046 & 0.119 \\
\hline & & $\begin{array}{l}\text { Rs.25001 } \\
50000\end{array}$ & & 0.46 & 0.208 \\
\hline & & & & $\begin{array}{l}\text { Rs.50001 to } \\
75000\end{array}$ & 0.686 \\
\hline
\end{tabular}

